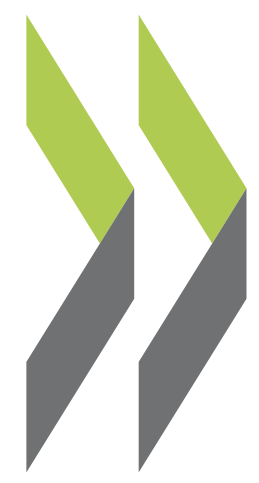

OECD Economics Department Working Papers No. 1123

Enhancing Competition and the Business Álvaro Pina Environment in Hungary 
Organisation de Coopération et de Développement Économiques

Organisation for Economic Co-operation and Development

04-Jun-2014

ECONOMICS DEPARTMENT

English - Or. English

ENHANCING COMPETITION AND THE BUSINESS ENVIRONMENT IN HUNGARY

ECONOMICS DEPARTMENT WORKING PAPERS No. 1123

\section{By Alvaro Pina}

OECD Working Papers should not be reported as representing the official views of the OECD or of its member countries. The opinions expressed and arguments employed are those of the author(s).

Authorised for publication by Alvaro Pereira, Director, Country Studies Branch, Economics Department.

All Economics Department Working Papers are available through OECD's Internet website at http://www.oecd.org/eco/workingpapers

JT03358725

Complete document available on OLIS in its original format

This document and any map included herein are with out prejudice to the status of or sovereignty over any territory, to the delimitation of international frontiers and boundaries and to the name of any territory, city or area. 
ECO/WKP(2014)19

OECD Working Papers should not be reported as representing the official views of the OECD or of its member countries. The opinions expressed and arguments employed are those of the author.

Working Papers describe preliminary results or research in progress by the author and are published to stimulate discussion on a broad range of issues on which the OECD works.

Comments on Working Papers are welcomed, and may be sent to the Economics Department, OECD, 2 rue André-Pascal, 75775 Paris Cedex 16, France, or by e-mail to eco.contact@oecd.org.

This document and any map included herein are without prejudice to the status of or sovereignty over any territory, to the delimitation of international frontiers and boundaries and to the name of any territory, city or area.

The statistical data for Israel are supplied by and under the responsibility of the relevant Israeli authorities. The use of such data by the OECD is without prejudice to the status of the Golan Heights, East Jerusalem and Israeli settlements in the West Bank under the terms of international law.

\section{(c) OECD (2014)}

You can copy, download or print OECD content for your own use, and you can include excerpts from OECD publications, databases and multimedia products in your own documents, presentations, blogs, websites and teaching materials, provided that suitable acknowledgment of OECD as source and copyright owner is given. All requests for commercial use and translation rights should be submitted to rights@oecd.org 
ECO/WKP(2014)19

\section{ABSTRACT/RÉSUMÉ}

\section{Enhancing competition and the business environment in Hungary}

Over the past decade, the growth potential of the Hungarian economy has declined substantially. Trend productivity has ceased to increase, and investment has fallen to historically low levels. To an important extent, the explanation lies in a business environment characterised by high administrative burdens, regulatory volatility, barriers to growth of small and medium-sized enterprises (SMEs) and entrepreneurship, and limited competition in major non-tradable sectors, problems which have sometimes become worse in recent years. Under these conditions, many SMEs find it hard to leave semi-informality and grow. Large multinational firms operating in manufacturing often have supplier networks weakly anchored in Hungary, while those in the non-tradable sectors sometimes face little competitive pressure; in both cases, positive spillovers to the domestic economy remain limited.

Steps should be taken both at the economy-wide level and in specific sectors to increase investment and restore productivity growth. Such measures must include fostering greater regulatory stability, inter alia by reducing the flow of new regulation and improving its quality, not least in taxation. Investor confidence would benefit from promoting trust and transparency in public institutions. Apart from vigorous competition enforcement across the economy, it is essential to remove sector-specific obstacles to competition, such as barriers to entry of different types, lock-in effects and distortive regulated prices, in retail, professional services, energy, and telecommunications. This Working Paper relates to the 2014 OECD Economic Survey of Hungary (www.oecd.org/eco/surveys/economic-survey-hungary.htm).

JEL classification: $H 2, K 2, L 4, L 8, L 9$

Keywords: Hungary, special taxes, productivity, business environment, administrative burdens, institutional quality, competition enforcement, barriers to entry, regulated prices, SMEs

$$
* * * * * * *
$$

\section{Renforcer la concurrence et améliorer le climat des affaires en Hongrie}

Le potentiel de croissance de l'économie hongroise a considérablement diminué au cours de la dernière décennie. La productivité tendancielle ne s'améliore plus et l'investissement est tombé à des niveaux historiquement bas. La raison de cette situation tient dans une large mesure à un environnement économique général caractérisé par des charges administratives élevées, une réglementation instable, des obstacles à la croissance des petites et moyennes entreprises (PME) et à l'entrepreneuriat, et une concurrence limitée dans les principaux secteurs non exportateurs, problèmes qui se sont en partie aggravés ces dernières années. Dans ces conditions, il est difficile pour beaucoup de PME de sortir de la situation semi-informelle dans laquelle elles se trouvent et de se développer. Quant aux grandes entreprises multinationales, celles qui sont présentes dans le secteur manufacturier ont souvent des réseaux de fournisseurs faiblement implantés en Hongrie, tandis que les autres, dans les secteurs non exportateurs, sont largement à l'abri des pressions de la concurrence ; dans un cas comme dans l'autre, par conséquent, les retombées positives de leurs activités sur l'économie nationale demeurent limitées

Des mesures générales et sectorielles s'imposent pour accroître l'investissement et rétablir la croissance de la productivité. Il est indispensable en particulier de promouvoir une plus grande stabilité réglementaire, notamment en réduisant le nombre de réglementations nouvelles et en améliorant leur qualité, surtout dans le domaine de la fiscalité. Une transparence accrue et une plus grande confiance dans les institutions publiques seraient en outre propices à l'investissement. Il est essentiel non seulement de veiller à ce que le droit de la concurrence soit vigoureusement appliqué de façon générale, mais aussi d'éliminer tout ce qui fait obstacle à la concurrence au niveau sectoriel, notamment les différentes formes de barrières à l'entrée, les effets de verrouillage et les distorsions induites par les prix réglementés dans le commerce de détail, les services professionnels, l'énergie et les télécommunications. Ce Document de travail se rapporte à l'Étude économique de l'OCDE de la Hongrie, 2014 (www.oecd.org/fr/eco/etudes/etude-economique-hongrie.htm).

Classification JEL : H2, K2, L4, L8, L9

Mots clefs: Hongrie, taxes spéciales, productivité, environnement des entreprises, charges administratives, qualité institutionnelle, concurrence, barrières à l'entrée, prix réglementés, PME 


\section{TABLE OF CONTENTS}

ENHANCING COMPETITION AND THE BUSINESS ENVIRONMENT ….................................... 5

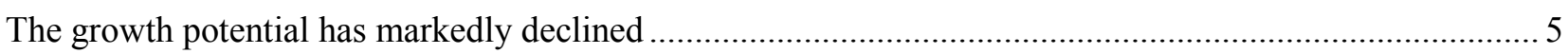

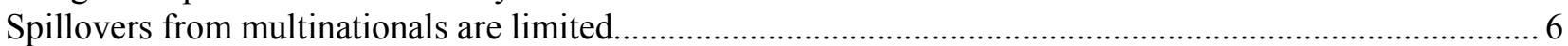

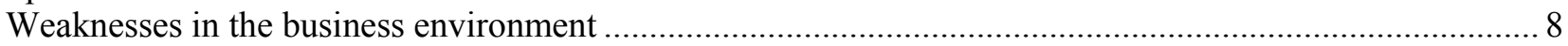

Reducing administrative burdens and regulatory instability ............................................................. 10

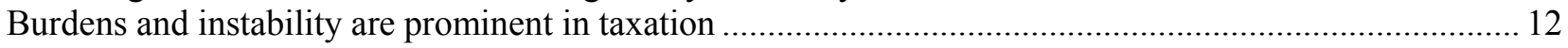

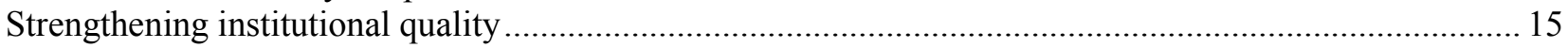

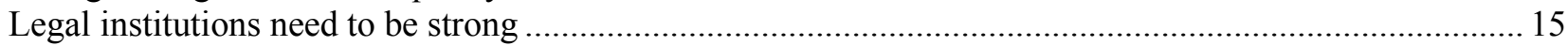

Preserving a broad and efficient competition enforcement..................................................................... 15

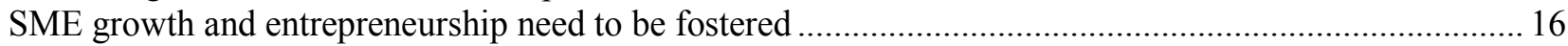

Barriers to entry are high in retail and professional services ................................................................ 17

Cuts in regulated energy prices harm competition, competitiveness and the environment ........................ 20

There is scope to increase competition in mobile communications.......................................................... 23

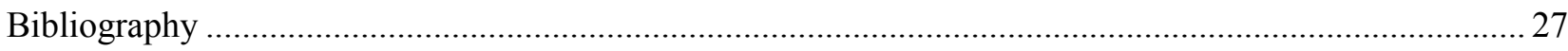

\section{Boxes}

Box 1. Recent administrative simplification programmes in Hungary ................................................. 11

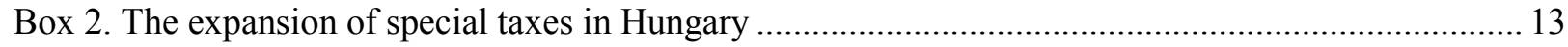

Box 3. The implementation of the 2013 energy price cuts................................................................... 21

Box 4. Main recommendations to enhance competition and the business environment .......................... 26

\section{Tables}

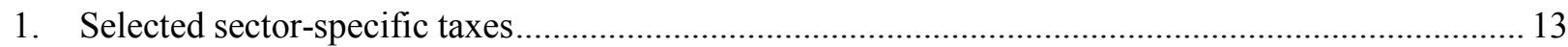

\section{Figures}

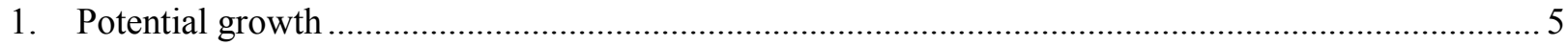

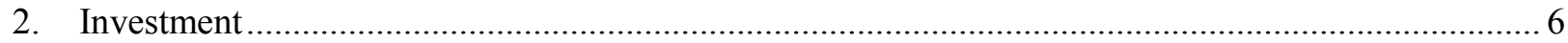

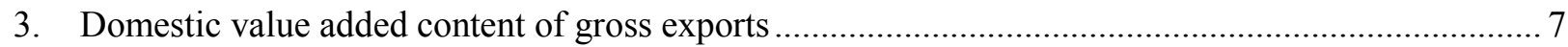

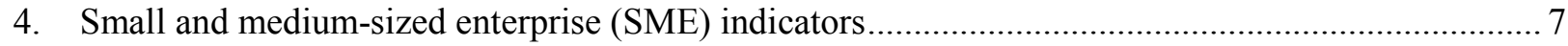

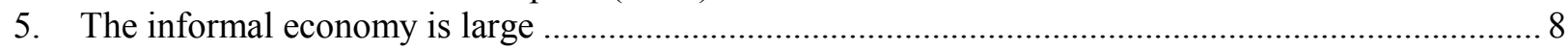

6. Contribution of allocation of employment across firms to manufacturing labour productivity........... 9

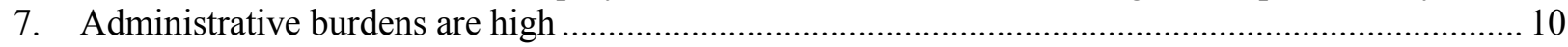

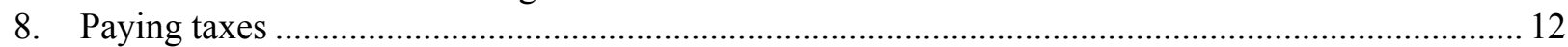

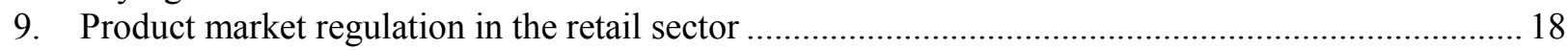

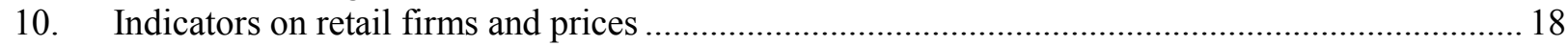

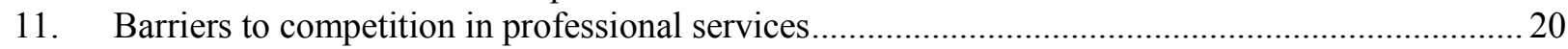

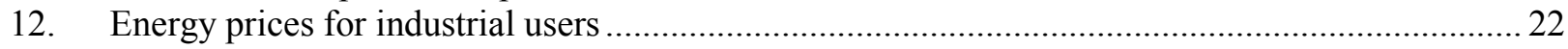

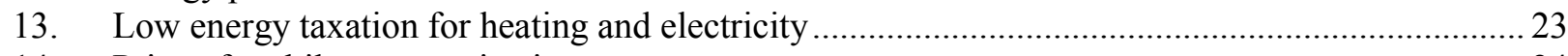

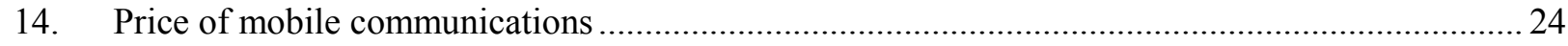

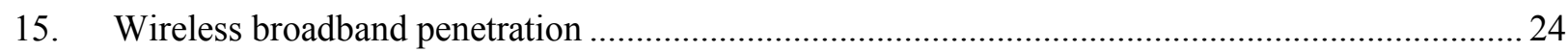




\title{
Enhancing competition and the business environment
}

\author{
By Álvaro Pina ${ }^{1}$
}

\section{The growth potential has markedly declined}

Over the past decade, the Hungarian economy has been falling behind its regional peers. Potential growth declined throughout the past decade, mainly reflecting adverse developments in total factor productivity (Figure 1). More recently, amidst widespread investment weakness, especially in Europe, potential output has also been hampered by a substantial slowdown in the pace of capital accumulation. The latter has been widespread but more pronounced in residential construction and in those sectors mainly dependent on the domestic market, such as energy and services, in sharp contrast to developments in the more outward-oriented manufacturing (Figure 2 and Martonosi, 2013). This overall disappointing economic performance permeates both strands of the largely dualistic Hungarian economy: large multinationals and domestic SMEs.

Figure 1. Potential growth

Contributions to potential output growth, percentage points ${ }^{1}$
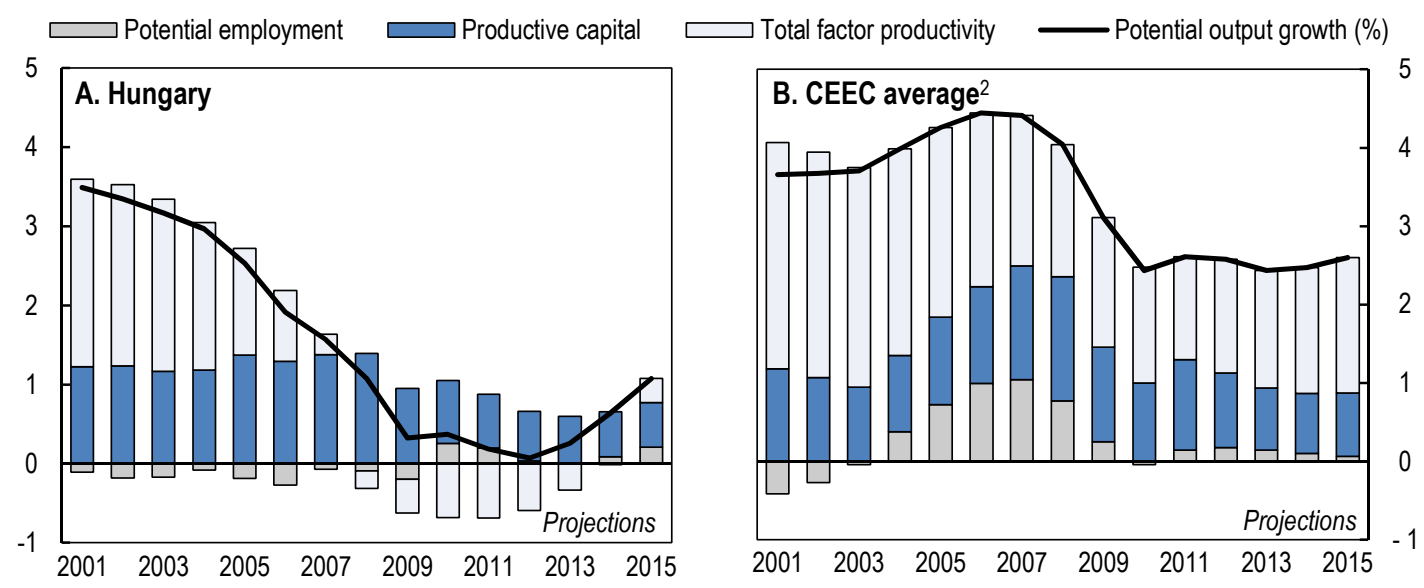

1. Contributions to growth are calculated using a weight of 0.67 for potential employment and 0.33 for productive capital; total factor productivity is calculated as a residual. Productive capital excludes investment in housing, while potential employment abstracts from cyclical variations in the labour force and unemployment.

2. Unweighted average of other Central and Eastern European countries (Czech Republic, Poland and Slovak Republic).

Source: OECD (2013), OECD Economic Outlook: Statistics and Projections (database), December.

1. This paper originally appeared as chapter 1 in the OECD Economic Survey of Hungary 2014, published in January 2014 under the authority of the Economic and Development Review Committee. Álvaro Pina is a senior economist in the OECD Economics Department. He is also affiliated with ISEG (Lisboa School of Economics and Management, Universidade de Lisboa) and UECE (Research Unit on Complexity and Economics, Lisboa). The author is grateful to Pierre Beynet, Filippo Cavassini, Andrew Dean, Robert Ford, Gábor Horváth and Stéphane Sorbe for valuable comments and suggestions on earlier drafts as well as for discussions with Hungarian government officials and independent experts. Special thanks go to Desney Erb for statistical assistance and Dacil Kurzweg for editorial assistance. 
Figure 2. Investment
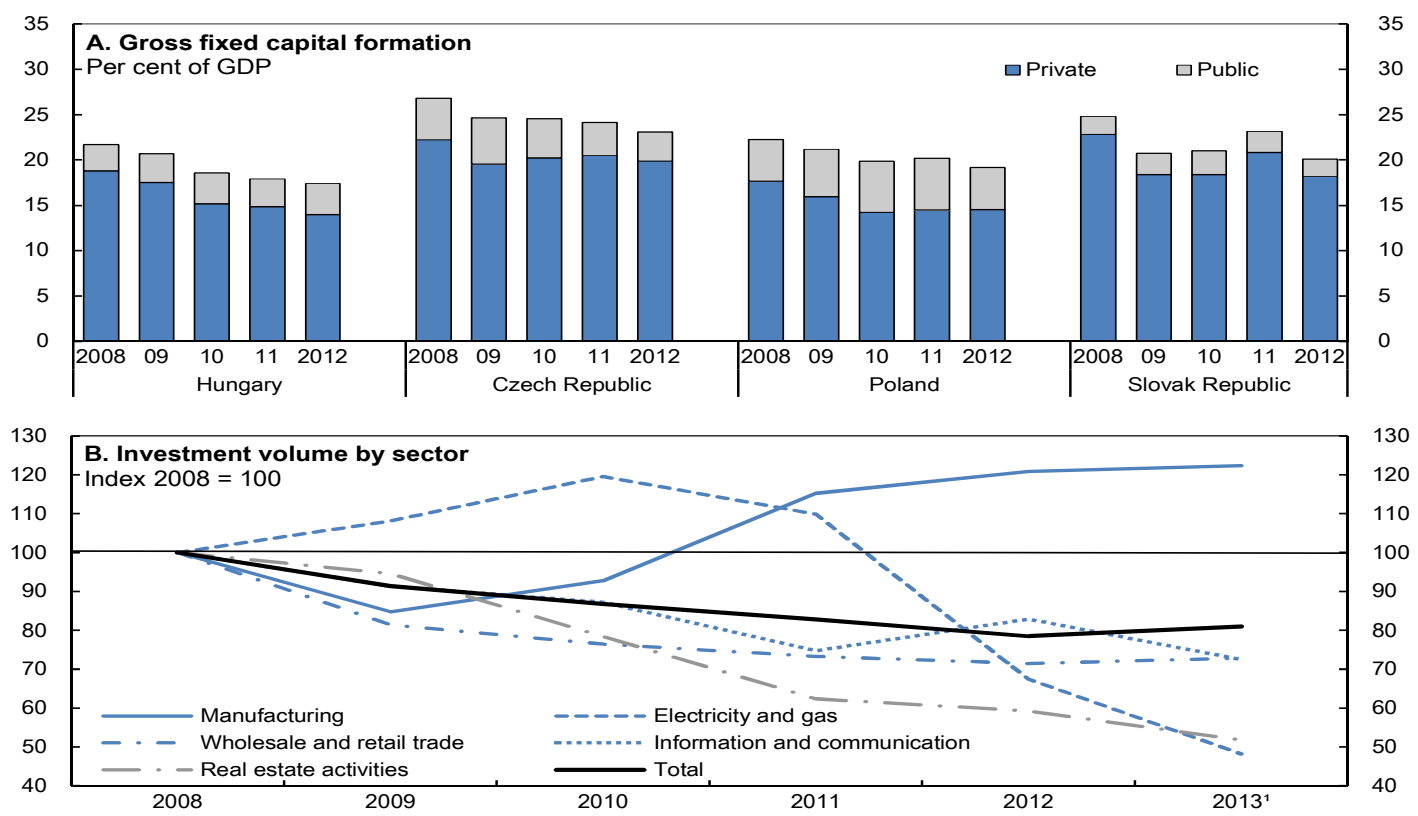

1. Estimate based on quarterly data available.

Source: OECD (2013), OECD National Accounts Statistics (database), December and HCSO (2013), "Business Units and Nonprofit Organisations", STADAT Tables, Hungarian Central Statistical Office, December.

\section{Spillovers from multinationals are limited}

Foreign direct investment (FDI) is a driver of dynamism and in the 1990s Hungary was among the first countries in the region to attract large FDI inflows, partly due to a faster privatisation process. As a result, multinationals came to dominate the main export-oriented manufacturing sectors, such as transport and electronic equipment, and sectors servicing the domestic market, such as energy, telecommunications and banking. However, international competition for FDI has become fiercer. Leading car manufacturers have expanded capacity in Hungary, but some prominent electronics multinationals have done the opposite, pointing to the risk of less FDI in the future.

Surprisingly, and worryingly, FDI in Hungary has often brought only limited benefits to economywide productivity. While manufacturing foreign affiliates account for most business enterprise research and development (R\&D) expenditure (0.75\% of GDP in 2011), multinationals' R\&D involvement in nontradable sectors like energy or telecommunications is low by international standards. In addition, the domestic value added content of gross exports is low in international comparison (Figure 3), especially in the manufacturing of transport and electronic equipment. This suggests that the supplier networks of multinationals in manufacturing are weakly anchored in Hungary (OECD and WTO, 2013; Tóth, 2013) and may explain why higher productivity in multinational firms did not percolate to the rest of the economy.

SMEs are relatively abundant relative to the population, but generally of very small size and low productivity (Figure 4, Panels A and B). Further, they are weakly inserted in international trade (or in the supply chains of larger firms) and seldom engage in R\&D or innovation (Figure 4, Panels C and D) though on the latter count recent years have witnessed some progress. Weaknesses in SMEs help explain their difficulty in liaising to multinationals and are accompanied, and to some extent induced, by a large informal sector (Figure 5), which tends to be associated with low productivity and slower firm growth (World Bank and IFC, 2013). 
Figure 3. Domestic value added content of gross exports ${ }^{1}$

Per cent, 2009

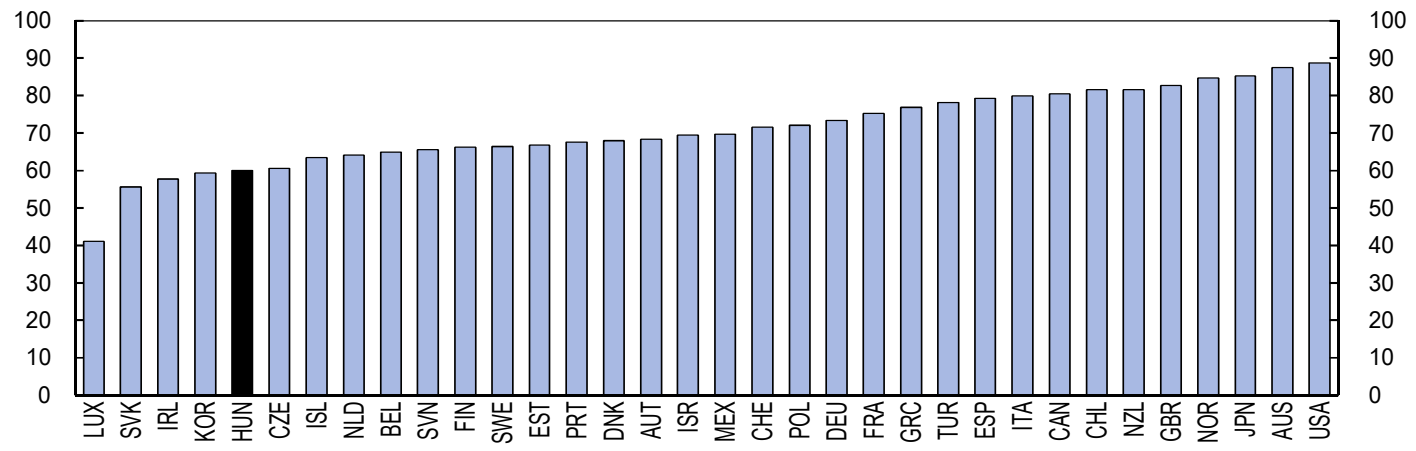

1. This reflects the total domestic value-added embodied in exports as a per cent of gross exports, illustrating how much valueadded is generated throughout the economy for a given unit of exports. The lower the ratio the higher the foreign content and so the higher the importance of imports to exports.

Source: OECD/WTO (2013), OECD-WTO: Statistics on Trade in Value Added (database), May.

Figure 4. Small and medium-sized enterprise (SME) ${ }^{1}$ indicators
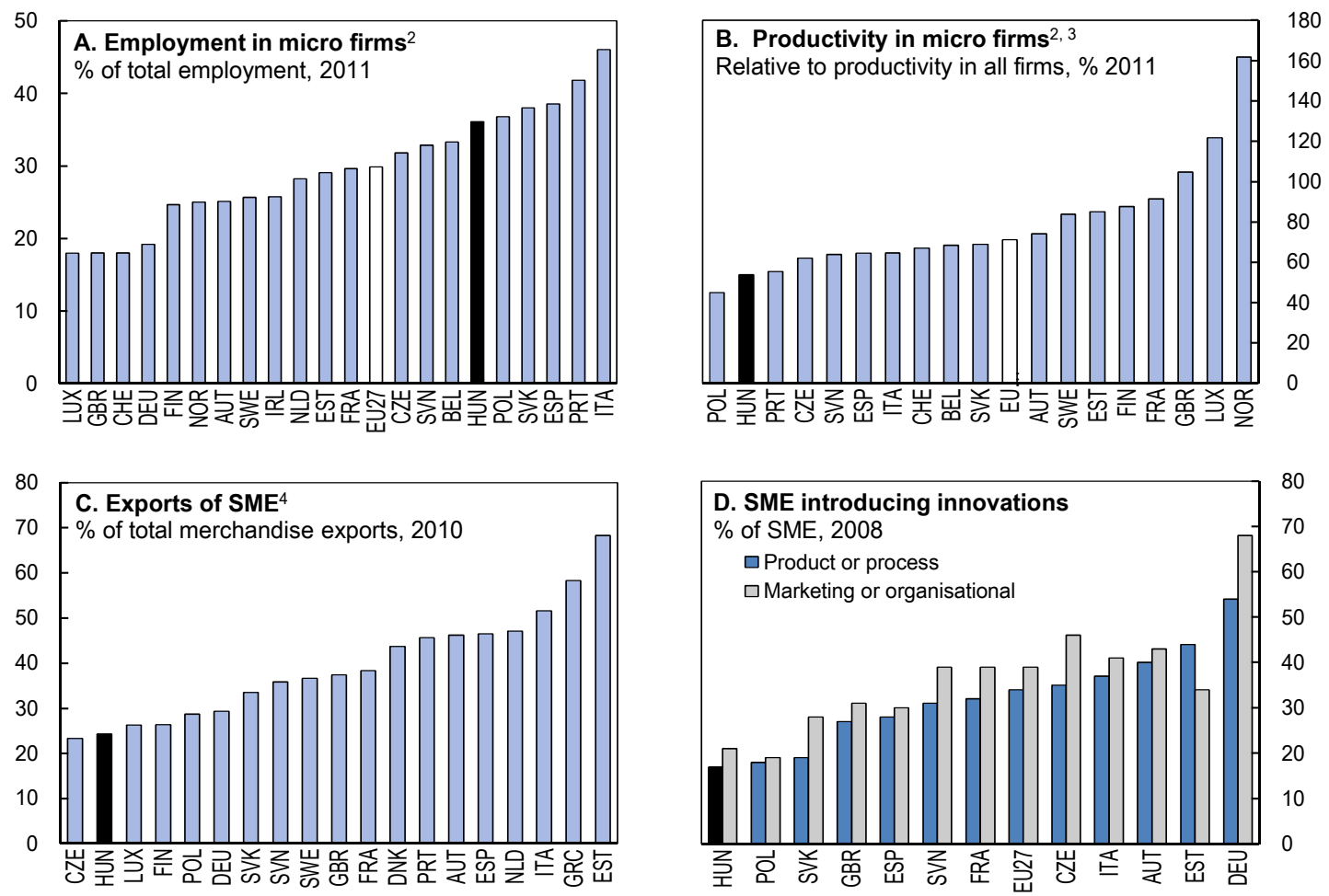

1. Enterprise size classes are based on the number of persons employed: a SME employs 0-249 persons and a micro firm employs $0-9$ persons.

2. The sector covered is the total business economy (including repair of computers, personal and household goods; excluding financial and insurance activities). Data for 2010 for Germany, Switzerland and the European Union aggregate.

3. Productivity is defined as value added at factor cost (in euros) per person employed.

4. Exports in US dollars for the total economy.

Source: Eurostat (2013), "Structural business statistics - Industry trade and services", Eurostat Database, December; OECD (2013), Entrepreneurship at a Glance 2013 and European Commission (2013), "SBA Fact Sheets 2013" for each country, DG Enterprise and Industry. 
Figure 5. The informal economy is large

Estimates in per cent of GDP
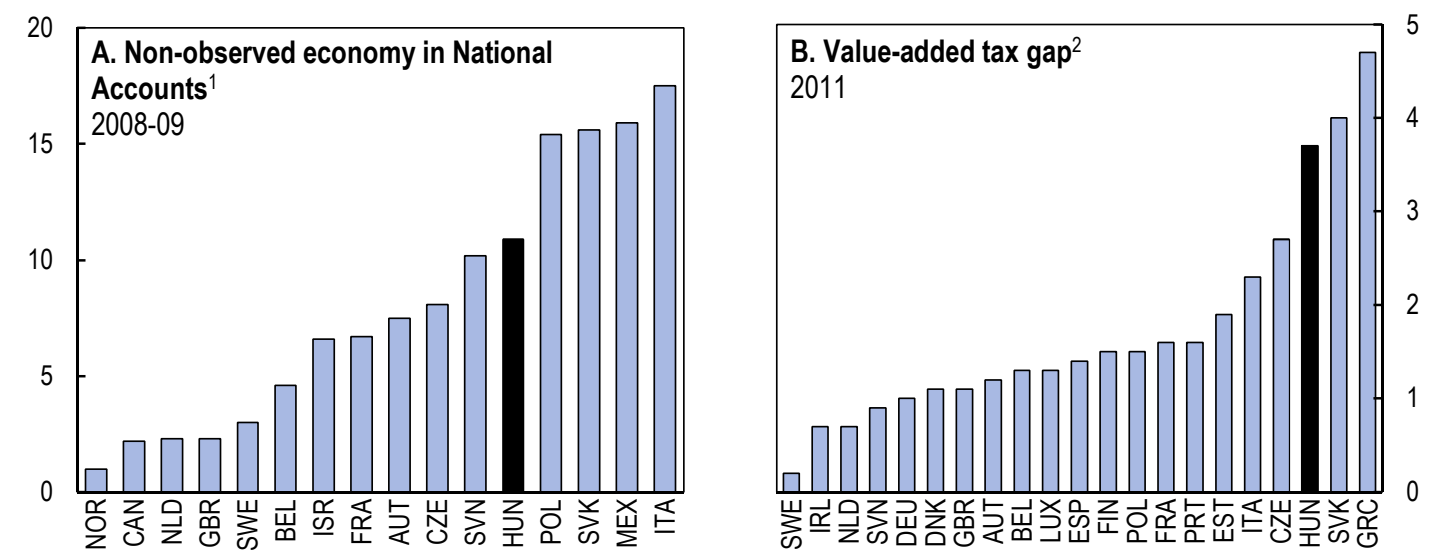

1. Numerical estimates of the non-observed economy (NOE) adjustments made to National Accounts based on responses to an OECD Survey carried out in 2012. The reference year of the responses varies from 2005 to 2009 with the large majority falling in 2008 or 2009. For details see the OECD document cited in the source.

2. The value-added tax (VAT) gap is the difference between the expected VAT revenues (account taken of reduced rates and exemptions) and VAT actually collected by national authorities. While non-compliance is certainly an important contributor to this revenue shortfall, the VAT gap is not only due to fraud. Unpaid VAT also results from bankruptcies and insolvencies, statistical errors, delayed payments and legal avoidance amongst other things.

Source: OECD (2012), "Summary of the OECD Survey on Measuring the Non-Observed Economy", Working Party on National Accounts, Committee on Statistics, Statistics Directorate, STD/CSTAT/WPNA(2012)21 and European Commission (2013), "Study to Quantify and Analyse the VAT Gap in the EU-27 Member States - Final Report", TAXUD/2012/DE/316, July.

\section{Weaknesses in the business environment}

Weaknesses in the business environment and problems of insufficient competition (some of which, though long-standing, have worsened in recent years) are key to explaining the above shortcomings. Regulatory instability, not least in taxation, deters investment. So do barriers to entry (Alesina et al., 2005), either sector-specific (see below) or of a cross-cutting nature, such as high administrative burdens. These dimensions of restrictive product market regulation also harm productivity, according to evidence available at aggregate, industry and firm levels (Arnold et al., 2011). Productivity growth is reduced both within firms (e.g. through less incentives to innovate) and between firms by penalising allocative efficiency (i.e. resource reallocation towards the most efficient companies in a sector), an area where Hungary performs below par (see Figure 6 and Andrews and Criscuolo, 2013). Difficult access to finance and cumbersome insolvency procedures also hamper resource reallocation. More generally, the perceived quality and effectiveness of legal and political institutions is modest and has tended to decline in the recent past. 
Figure 6. Contribution of allocation of employment across firms to manufacturing labour productivity ${ }^{1}$

In selected OECD countries, log points, 2005

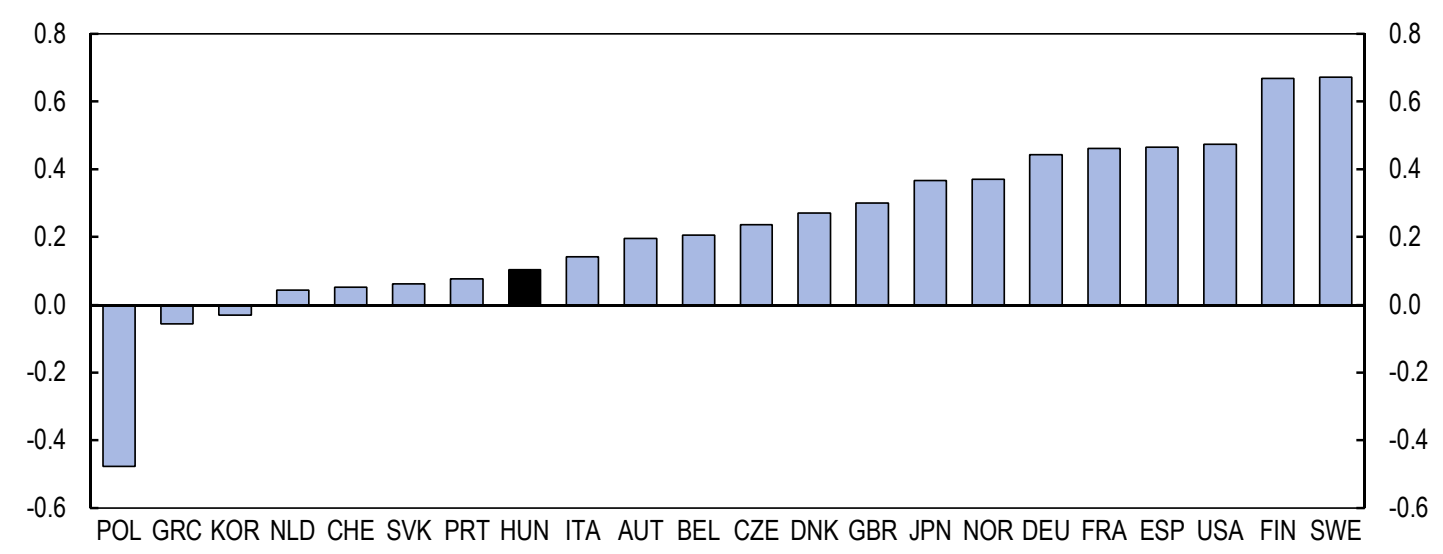

1. The estimates show the extent to which the firms with higher than average labour productivity have larger employment shares in the manufacturing sector. In most countries, the covariance between productivity and employment share is positive, suggesting that the actual allocation of employment boosts manufacturing labour productivity (e.g. by around $50 \%$ in the United States), compared to a situation where resources were allocated randomly across firms (this metric would equal zero if labour was allocated randomly). See source publication for further details.

Source: D. Andrews and F. Cingano (2012), "Public Policy and Resource Allocation: Evidence from Firms in OECD Countries", OECD Economics Department Working Papers, No. 996.

Competitive pressures are limited in some mostly non-tradable sectors, such as retail, professional services, energy and telecommunications. This is mainly due to high barriers to entry and, in energy, distortive price regulation. While empirical evidence on mark-ups in Hungary is scarce, especially in the non-manufacturing sectors, Bottini and Molnár (2010) report an internationally high value in retail trade. In telecommunications and energy, Hungarian price levels are often comparatively high, pointing to potentially high mark-ups. Negative impacts are substantial. Some evidence suggests that within service sectors anti-competitive regulation has a strong detrimental impact on allocative efficiency and therefore on productivity growth (Andrews and Cingano, 2012). Further, the effects extend to countless downstream industries, where the scope and incentives for productivity improvements can be reduced. For instance, restrictive regulation of professional business services slows down the growth of patenting firms across the economy (Andrews et al., 2013).

SMEs are disproportionately affected by administrative burdens and thus often choose to slide into semi-informality, which thwarts their growth and makes it harder to change banks or suppliers of professional services (Balás et al., 2010; World Bank and IFC, 2013). SMEs are also hit hardest by financing constraints, which compounds the barriers to their growth and therefore to their ability to challenge larger competitors. Hampered resource reallocation towards dynamic young firms likely decreases the incentives to innovate in the first place (Andrews and Criscuolo, 2013). In turn, lowinnovation firms generally have a weaker export performance (Halpern and Muraközy, 2012). As in other countries with a strong presence of foreign firms and low domestic value added content of gross exports, like Ireland, supporting the development of innovative SMEs would also help foster spillovers from multinationals, inter alia through joint R\&D efforts or high-skilled labour mobility between the two sets of firms (OECD, 2013a).

This paper proposes reforms to improve product market regulation and thus foster investment and productivity growth in the Hungarian economy, discussing first problems felt across the economy and then addressing barriers to competition in specific service and utilities sectors. 


\section{Reducing administrative burdens and regulatory instability}

There is abundant evidence of high administrative burdens in Hungary, both from indicators based on a cross-country comparison of prevailing regulations and from surveys based on business perceptions (Figure 7). An example of the latter is the Global Competitiveness Report (World Economic Forum, 2013), where in 2012 Hungary ranked 140th among 148 countries as regards the perceived burden of government regulation. Burdens are generally compounded by regulatory instability and uncertainty, which, if anything, have worsened in recent years, with executives often singling out policy instability, together with hard access to financing, as the most problematic factor for doing business (World Economic Forum, 2012 and 2013).

\section{Figure 7. Administrative burdens are high ${ }^{1}$}

Index scale of 0-6 from least to most restrictive

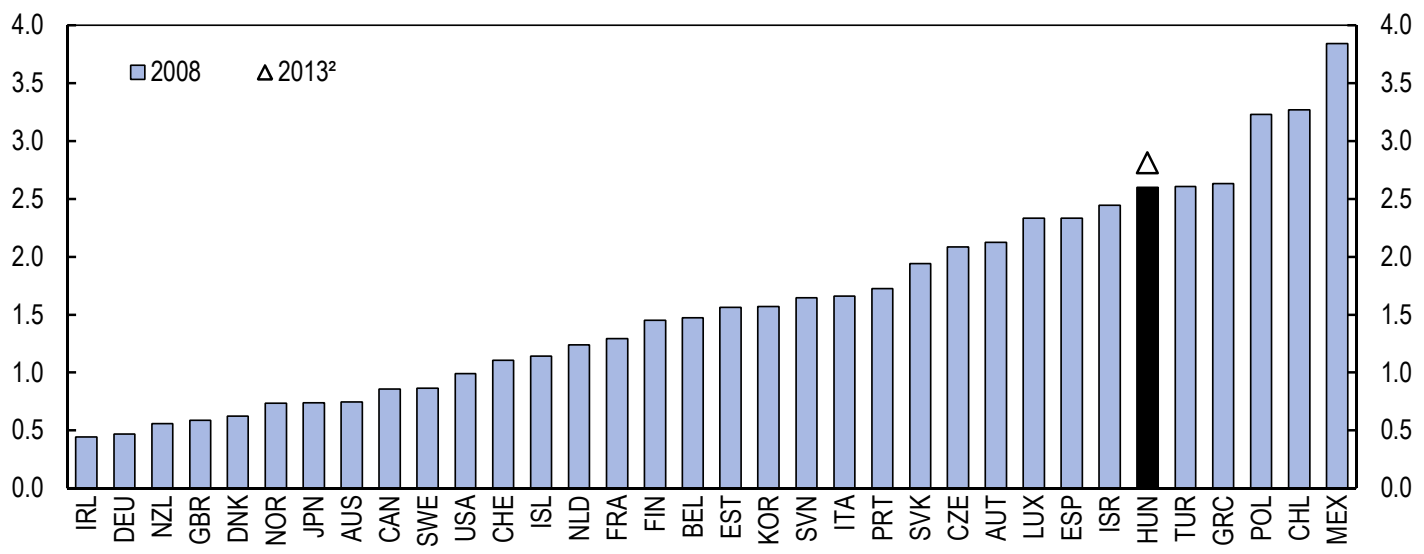

1. The product market regulation indicator for administrative burdens is composed of the following three elements (equal weights): administrative burdens for corporations, administrative burdens for sole proprietor firms and sector specific administrative burdens (road transport and retail distribution).

2. Preliminary data calculated on the basis of the 2008 methodology for purposes of comparability. For more details, see Koske et al. (2014) which provides the 2013 indicators with a revised methodology.

Source: OECD (2013), OECD Product Market Regulation Statistics (database), July and I. Koske, I. Wanner, R. Bitetti and O. Barbiero (2014), "The 2013 Update of the OECD Product Market Regulation Indicators: Policy Insights for OECD and non-OECD Countries", OECD Economics Department Working Papers, forthcoming.

The authorities have long been aware of these problems and have made several attempts over the years to tackle them. In 2011, as part of an overall government strategy to improve the business environment, two ambitious administrative simplification programmes were launched, one addressed at citizens (the Magyary Programme, led by the Ministry of Public Administration and Justice) and the other at firms (the Cutting Red Tape Programme, led by the Ministry for National Economy). Wide-ranging in nature, these programmes have made important strides in streamlining existing regulations (Box 1). However, further progress requires reducing the flow of new regulation while improving its quality, persevering with efforts at greater coordination among different agencies (not least in information-sharing), and promoting greater transparency and stakeholder involvement in programme monitoring. 


\section{Box 1. Recent administrative simplification programmes in Hungary}

The Magyary Programme, which has benefitted from a strategic assessment and capacity development advice from the OECD, ${ }^{*}$ aims at both administrative simplification for citizens and public administration reform. Under the former strand, 228 procedures were simplified, in areas as diverse as family matters, taxation, employment and social assistance, with stronger reliance on interactions with the administration through electronic means (e-administration). While the Programme still awaits a formal evaluation, its goal was to decrease administrative burdens on citizens by more than $25 \%$. Additionally, the authorities have been developing a network of one-stop-shops, which in July 2013 had reached 29 offices able to deal with 150 administrative procedures. Plans to expand the network to 300 shops handling around 2500 procedures by end-2013 have been revised and rescheduled for 2014. As regards public administration reform, the Magyary Programme comprises actions to promote capacity building among civil servants, for instance through training in ex ante regulatory impact assessment, as well as efforts to fight corruption.

As regards simplification steps addressed to firms, 93 out of the 114 measures initially envisaged under the Cutting Red Tape Programme had been implemented by the end of 2013. Official estimates based on the standard cost model suggest that the administrative burden of businesses decreased by around HUF 210 billion per year $(0.7 \%$ of GDP). Over $40 \%$ of this reduction has been achieved in taxation and accounting, identified as the most burdensome areas, inter alia by extending e-administration, decreasing the number of payments to the tax authority by allowing the merger of various payments into one single money transfer and streamlining public health insurance administration. Simpler procedures when applying for European Union funds and building permits are also noteworthy, as is the reduction from 30 to 21 days in the general deadline for a public authority to finish a procedure. Further, implemented measures extended to the areas of transportation, environmental protection, agriculture and legal protection. Measures still pending are mostly connected to e-government (e.g. interoperability of databases and extension of electronic data provision), which has a large potential for further improvement. Based on the encouraging results obtained so far, the government is planning to launch a second phase of the Cutting Red Tape Programme.

* OECD (forthcoming), Hungary: Towards a Strategic State Approach, OECD Public Governance Reviews, OECD Publishing

While the stock of pre-existing burdens has been curtailed, new regulation, sometimes poorly prepared, has relentlessly kept flowing. The requirements for and the extent of Regulatory Impact Assessment (RIA) processes in Hungary have traditionally been below-average (OECD, 2009). In 2011 RIA was made compulsory for government-originated legislation, and technical capacity for that purpose started to be built at the two ministries that are leading the administrative simplification effort. However, ensuring high-quality RIA which is able to cover economic, social and environmental impacts is still challenging, for reasons as diverse as insufficient staff training, the lack of an evaluation culture or shortcomings in information systems (such as the need to know, for instance, how many firms will be affected by a new regulatory requirement). The authorities should thus continue ongoing efforts to tackle these problems, and regularly publish RIA outputs.

The situation is worse as regards parliament-initiated bills, which account for a growing share in total legislation (around 36\% of all laws adopted between the 2010 elections and September 2013, up from 19\% in the 2006-10 legislature). They are not subject to RIA, with even consultation of affected parties being left at the discretion of parliamentarians. Mandatory consultations with experts and stakeholders should be introduced, and the opinions delivered in those consultations made public. Further, secondary legislation detailing and implementing primary legislation should be timely and transparent.

Successful administrative simplification requires strong intra-government coordination, which is still challenging in some areas. Though the two simplification programmes were initially assigned to different ministries, with limited exploitation of the synergies between measures for citizens and for firms (OECD, forthcoming), coordination improved with the later creation of a high-level Task Force (led by the Ministry of Public Administration and Justice) to monitor both programmes in May 2012. However, the need for increased coordination remains particularly pressing as regards information sharing and database integration, as the large burdens from information obligations (Deloitte, 2009) are partly induced by repeated reporting to different agencies. The authorities are currently preparing the legal conditions for the 
interoperability of state-owned databases, with full implementation expected to extend beyond 2014 (Government of Hungary, 2013). These efforts should be continued with a high priority, without neglecting appropriate safeguards for data privacy and security.

Finally, the authorities should further promote systematic stakeholder involvement in programme monitoring, the results of which should be made public. So far, monitoring has essentially taken the form of internal government reports, and interactions with stakeholders have been insufficient for programme steering, though stakeholders were initially involved in programme design. However, regular interactions help to make agencies more aware of firms' and citizens' needs, nurture mutual trust and provide valuable feedback on implementation, enabling corrective interventions if a gradual approach is taken. On this latter count, earlier plans for an extremely rapid expansion of one-stop-shops in 2013 (see Box 1) provide a counter-example. Publicly-available reports on progress in implementation foster transparency and raise the political profile of simplification efforts, thus reinforcing the momentum for reform.

\section{Burdens and instability are prominent in taxation}

Taxation is a major area where economic agents face burdensome and unstable rules, accounting in some studies for over $40 \%$ of total administrative burdens from information obligations (Deloitte, 2009). According to Paying Taxes 2014 (World Bank et al., 2013), a Hungarian SME spends 277 hours per year complying with tax obligations, 50\% more than the OECD average, although not much different from other Central and Eastern European countries (Figure 8). The administrative costs of tax collection, either relative to GDP or to tax revenue, are also high in international comparison (OECD, 2013b). Explanations include a high number of different taxes as well as complex and unstable tax laws, partly due to sizeable tax expenditures (amounting to almost 4\% of GDP in 2013 according to official estimates).

Figure 8. Paying taxes

Time taken to prepare, file and pay taxes, hours per year ${ }^{1}$

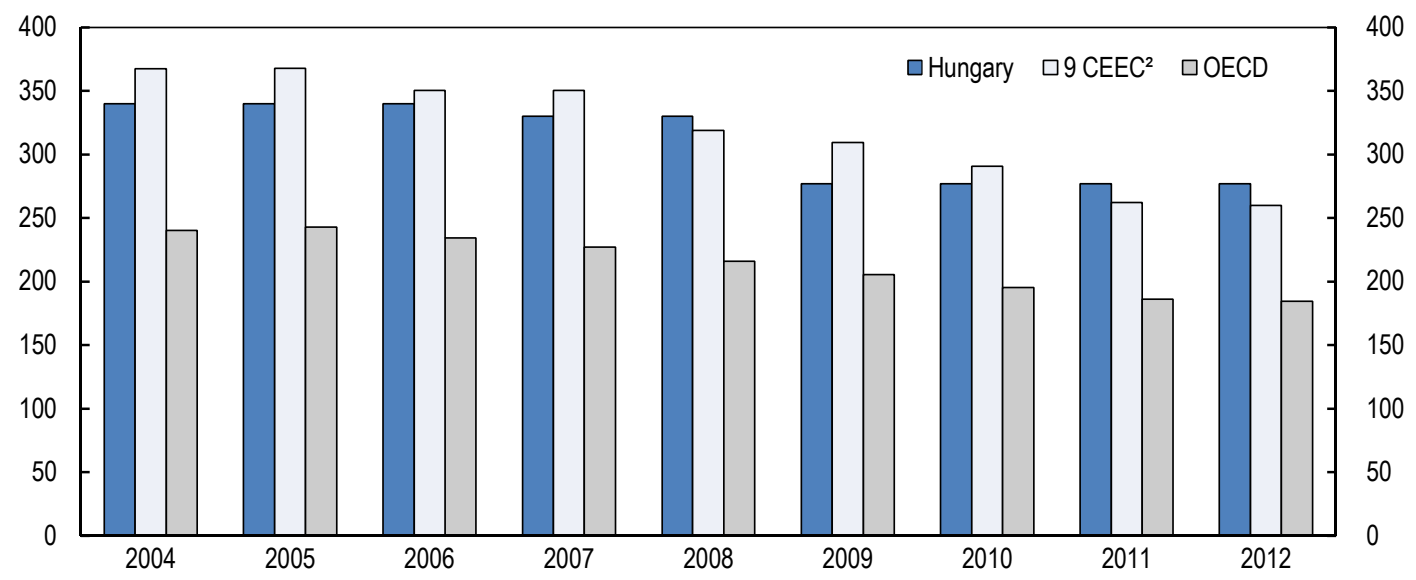

1. Corporate income tax, value added or sales tax, and labour taxes (including payroll taxes and social security contributions). Zone aggregates are unweighted averages.

2. Central and eastern European EU member countries: Bulgaria, Czech Republic, Estonia, Latvia, Lithuania, Poland, Romania, Slovak Republic and Slovenia.

Source: World Bank (2013), World Development Indicators, World DataBank (database), November and www.doingbusiness.org.

In recent years, the proliferation of successively amended special taxes (not included in the above estimate of the time needed for compliance) has compounded instability and uncertainty (Box 1.2). While these taxes have contributed to fiscal consolidation and helped avoid a higher tax burden on labour, the associated regulatory volatility has deterred investment. Some of these taxes have also had further adverse 
impacts on investment, such as those stemming from the sharp deterioration in the profitability of banks and therefore in their ability to extend credit (the levy on financial institutions (Box 2) being particularly harmful on this count), or may distort competition when tax design penalises some firms more than others (as discussed below in the context of telecommunications). The authorities should gradually scale down these special taxes and improve the design of the most distortive ones. An analysis of how to improve bank taxation can be found in the financial stability chapter of the 2012 OECD Economic Survey of Hungary (OECD, 2012) and in Havrylchyk (2012).

\section{Box 2. The expansion of special taxes in Hungary}

Since 2010 there has been a steep increase in revenue from taxes with statutory incidence on a limited number of sectors, namely finance, energy, telecommunications and retail (Table 1). Existing taxes have been modified and new ones introduced, often with several subsequent revisions, as summarised below.

Table 1. Selected sector-specific taxes

Billion HUF

\begin{tabular}{|c|c|c|c|c|c|c|}
\hline & 2008 & 2009 & 2010 & 2011 & 2012 & $2013^{1}$ \\
\hline Finance & 12.6 & 12.6 & 192.3 & 195.9 & 94.6 & 373.9 \\
\hline Levy on financial institutions & . & 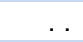 & 182.3 & 186.5 & 84.9 & 139.1 \\
\hline Extra tax on selected financial institutions ${ }^{2}$ & 12.6 & 12.6 & 10.0 & 9.4 & 9.7 & 8.1 \\
\hline Financial transaction tax (excluding Treasury) & . & . & . & . & . & 200.5 \\
\hline Insurance tax & . & . & . & . & . & 26.2 \\
\hline Energy & . & 24.2 & 81.2 & 115.9 & 87.2 & 98.9 \\
\hline Income tax on energy service providers & . & 24.2 & 17.0 & 16.9 & 5.6 & 54.1 \\
\hline Surtaxes payable by certain economic sectors & .. & . & 64.2 & 99.0 & 81.6 & 3.9 \\
\hline Tax on wires and pipelines & . & . & & . & . & 40.9 \\
\hline Telecommunications & . & . & 58.6 & 51.3 & 62.9 & 61.7 \\
\hline Surtaxes payable by certain economic sectors & . & . & 58.6 & 51.3 & 50.7 & 3.7 \\
\hline Tax on wires and pipelines & . & . & . & . & . & 14.0 \\
\hline Telecommunications tax & . & . & . & . & 12.2 & 44.0 \\
\hline Retail & . & . & 28.9 & 21.6 & 33.3 & 2.2 \\
\hline Surtaxes payable by certain economic sectors & & & 28.9 & 21.6 & 33.3 & 2.2 \\
\hline Total & 12.6 & 36.8 & 361.0 & 384.7 & 278.0 & 536.7 \\
\hline In \% of GDP & 0.0 & 0.1 & 1.4 & 1.4 & 1.0 & 1.8 \\
\hline
\end{tabular}

1. Preliminary budgetary data.

2. The amounts for 2013 exclude the technical adjustments introduced to ensure equal burden-sharing between banks and the state as regards debt forgiven under the exchange rate cap scheme (a foreign exchange mortgage relief scheme).

Source: State Treasury, Ministry for National Economy.

Since 2007 credit institutions have had to pay a special tax (the extra tax on selected financial institutions) on interest income from state-subsidised loans. This tax replaced the extraordinary tax on financial institutions, introduced in 2005.

In 2010 taxes on the financial sector were expanded with the introduction of the levy on financial institutions, falling on the adjusted balance sheet amount at end-2009. A $0.15 \%$ rate is applied up to HUF 50 billion, beyond which the marginal rate rises to $0.53 \%$. In 2012 , some losses from the foreign exchange mortgage early repayment scheme (which allowed debtors to pay off their mortgages at a concessionary exchange rate) and from debts overdue more than 90 days could be deducted, the same holding for the increase in the credit portfolio towards SMEs (which has remained deductible to date). According to April 2012 Convergence Programme plans, this tax would have been halved in 2013 and further reduced in 2014. In October 2012, however, the authorities decided to postpone halving to 2014 , and one month later to retain the tax indefinitely and in full. Insurance companies have been exempted from this tax since 2013 and a consumption-type insurance tax was introduced instead, falling on 
insurance premia (except for life insurance).

The financial transaction tax (FTT), in force since 2013, is levied on most transactions of financial institutions and the Treasury, including money transfers, cash withdrawals and amortisation of loans, among others. The FTT was initially supposed to replace the levy on financial institutions, and the law creating it (July 2012) set a rate of $0.1 \%$. In the autumn, however, the general rate was increased to $0.2 \%$, with a higher rate $(0.3 \%)$ charged on cash withdrawals. A ceiling of HUF 6000 per transaction generally applied. Because of large revenue shortfalls, the authorities increased rates again to $0.3 \%$ ( $0.6 \%$ on cash withdrawals), effective from August 2013 , and abolished the ceiling for cash withdrawals. Further, banks were required to make a one-off payment of HUF 75 billion in the autumn. Banks, nonetheless, have generally succeeded in shifting the FTT to their clients through increased service fees (MNB, 2013). * A November 2013 amendment attempts to limit this pass-through by making individuals entitled to two free cash withdrawals per month (on which banks still have to pay FTT) up to a total HUF 150000 from February 2014 onwards.

Turnover-based surtaxes payable by certain economic sectors (energy, telecommunications and retail) were introduced in December 2010, retroactively covering 2010, and phased out, as planned, at end-2012, leaving retail special-tax-free. Each sector concerned had its own schedule of progressive tax rates.

The income tax on energy service providers (nicknamed the Robin Hood tax) was introduced in 2009 as a temporary tax to last for two years (2009-10). It fell on pre-tax profit at a rate of $8 \%$. The tax has stayed on after 2010 and the April 2012 Convergence Programme envisaged to double it to $16 \%$ in 2013. The planned 2013 rate was later revised downward to $11 \%$ and finally raised to $31 \%$ in November 2012 (with an up to $50 \%$ deduction for certain types of job creating investments). Since 2013, the range of companies liable to pay this tax has also been broadened with the inclusion of electricity and natural gas distribution system operators and universal service providers.

A tax on wires and pipelines, falling on the owners of utility networks, came into force in January 2013, set at a rate of HUF 125 per meter of ducts providing for electricity, natural gas, heating, water and wastewater services. For telecommunications, the marginal rate is progressive on the length of the network, ranging from HUF 25 to the standard HUF 125 per meter. The legislation was proposed and passed within only five days in November 2012. According to plans made one month earlier the tax would have been local and optional. State and municipality owned enterprises are exempt.

A telecommunications tax on fixed and mobile voice calls and mobile SMS/MMS services has been effective from July 2012, set at HUF 2 per minute of calls and per SMS/MMS, with monthly caps per calling number of HUF 400 for private individuals and HUF 1400 for other subscribers. These caps were increased to HUF 700 and HUF 2 500, respectively, at the beginning of 2013. In August 2013 the tax for other subscribers was increased to HUF 3 per minute or message with a monthly ceiling of HUF 5000.

* $\quad$ MNB (2013), Report on Payment Systems, Magyar Nemzeti Bank.

The authorities have taken some welcome steps to reduce burdens in taxation, but there is still much room for improvement. Substantial progress has been made over the past decade in electronic tax filing by firms (OECD, 2013b). More recently, some minor taxes were abolished, and in 2013 tax payments were streamlined (Box 1) and two simplified corporate tax schemes addressed at micro enterprises (KATA, a lump-sum tax) and at small firms (KIVA, a cash-flow-based one) were introduced, though take-up has been more gradual than anticipated and previous preferential schemes for SMEs have remained in force. The merger of tax and customs operations into the National Tax and Customs Administration (2011) has the potential to reduce compliance costs (as the integration of social contributions collection into the tax agency gradually did in the past) as well as to enable a more effective fight against tax fraud and evasion. In pursuing the latter, however, the authorities should avoid creating excessive information burdens on complying taxpayers, as it could be the case with the recent requirement to detail VAT returns on a per invoice basis.

Consolidating several related taxes into fewer and broader ones is an important avenue for simplification. For instance, the five different types of social contributions (all falling on the gross wage, but nonetheless with some divergence in rules) could be unified, and older forms of preferential corporate 
income taxation for SMEs reconsidered as new schemes are introduced. Also, the authorities should aim at greater stability of tax rules, notably by rolling back tax expenditures and other special provisions (reduced rates of value-added tax [VAT], which go well beyond essential food staples, being a case in point) and significantly reducing the flow of new ones. By reducing uncertainty and compliance costs, simpler and more stable tax rules would also pave the way for greater trust and transparency in the relationship between firms and the tax administration (Balás et al., 2010).

\section{Strengthening institutional quality}

\section{Legal institutions need to be strong}

A stable and efficient legal framework, grounded on the principles of separation of powers and judicial independence, is widely seen as growth-enhancing (North, 1990; Rodrik et al., 2004). Furthermore, transparency and trust decrease transaction costs and help foster a level playing field for business. In Hungary, however, the perceived quality and effectiveness of legal and political institutions is weak. While inevitably subjective, perceptions help shape investor sentiment, with implications ranging from exchange rate stability to fixed capital formation. Hungary performs poorly on an indicator of civic engagement and governance (OECD, 2013c), and ranks 84th among 148 countries in the institutional component of the Global Competitiveness Index (World Economic Forum, 2013). In the latter, besides administrative burdens, trust and transparency in policymaking and the efficiency of the legal framework in enabling firms to challenge government regulations are seen as particularly problematic. Over the past few years, Hungary has gone down in the rankings in most of these areas. Citizens' perceptions of corruption have also worsened (Transparency International, 2013).

Some recent developments have not helped to foster transparency and trust in public institutions. Constitutional changes have proved controversial (Venice Commission, 2013; European Parliament, 2013). Legislation has reinforced the statutory independence of sectoral regulators, a welcome goal, but has also limited the possibilities of appeal. Energy or media firms, for instance, can only challenge the general regulations by the respective sectoral agencies at the Constitutional Court, instead of ordinary courts arrangements which, while not unprecedented in Europe, may be problematic. Further, the decisions of the media regulator in individual cases, which may include hefty fines, are to be immediately enforced regardless of any subsequent appeal to courts. In the context of tobacco monopolisation (see below), important legal amendments (namely raising the profit margin and enlarging the range of other products licensed retailers are allowed to sell) took place after the closing date for applications for retail licences. Well communicated steps towards stronger checks and balances, as discussed in the 2012 OECD Economic Survey of Hungary (OECD, 2012), are therefore important. Reputation and credibility would also benefit from giving priority to people widely regarded as non-affiliated to political parties in future appointments to boards of independent agencies, either those with macroeconomic or sectoral roles (Thatcher, 2005; Gilardi and Maggetti, 2010).

\section{Preserving a broad and efficient competition enforcement}

Recent developments have limited the ability of the Hungarian Competition Authority (GVH) to enforce and promote competition. According to competition law, any draft bills or regulations which may affect competitive conditions or the operation of markets must be submitted to the GVH for an opinion. However, both parliamentarians and the government have long been reluctant to do so, and the problem is arguably getting worse (the number of yearly submissions declined from around 500 in 2007 to 115 in 2012), making it harder for the GVH to exert a pro-competitive influence in law-making. Non-submission is due either to decisions of the legislation proponents or to the general exemption of consultation obligations for parliament-initiated bills. The authorities should systematically consult the GVH in relevant matters, as well as any sectoral regulators concerned. Further, enough time should be allowed for the 
delivery of an informed opinion, any departures from which the authorities should be asked to publicly justify.

Also of concern are recent developments curtailing the scope of competition law. A legal amendment in force since November 2012 exempts, under certain conditions, agricultural products from competition rules on cartels. Conditions give considerable leeway for interpretation (for instance, whether the anticompetitive effects of a cartel agreement exceed what is necessary to ensure a fair income to producers) and are assessed by the Minister of Rural Development, whom the GVH must consult in any proceeding involving those products. While so far the only exemption has been granted to watermelon producers and retailers, halting the investigation of an alleged cartel which the GVH had started before the legal amendment, the new rules have the potential to severely restrict competition in retailing. Further, 2013 legislation empowers the government to bypass the GVH in authorising mergers considered to be of national interest. Again, the criteria to be fulfilled - such as the need to protect jobs or to ensure secure supply - leave substantial room for interpretation. To reverse these trends, the authorities should expand rather than restrict the scope of application of competition law.

The GVH continues to foster capacity building in the region through the dedicated operation of the OECD-GVH Regional Centre for Competition in Budapest, and has achieved major efficiency gains in merger control through more systematic pre-notification contacts with interested parties, the creation of a dedicated merger section and streamlined procedures for non-problematic deals. Though internal restructuring has also taken place in antitrust, the enforcement record in this area has so far won less praise (Global Competition Review, 2013). In 2011-12, the average length of cartel investigation substantially increased, leading to fewer decisions. Advocacy work has also likely decreased, as it has mainly consisted in reacting to a decreasing number of draft bills submissions (though the GVH took on some occasions the initiative of sending comments directly to the legislation proponents), with less use of active advocacy tools, such as sectoral inquiries (the recent investigation into the market of online room reservations in the tourism sector, launched in July 2013, was the first such new inquiry since 2010). Drawing on the efficiency gains achieved in mergers, the GVH should step up work in antitrust enforcement and further active competition advocacy.

\section{SME growth and entrepreneurship need to be fostered}

Despite some recent improvement, access to finance is still identified as the most pressing problem by $17 \%$ of Hungarian SMEs, against $15 \%$ in the European Union (EU) average (European Commission, 2013a). In a similar vein, lack of capital is seen as the main obstacle to self-employment and entrepreneurship (OECD, 2013d). Repairing bank balance sheets by recognising losses from nonperforming loans and avoiding "evergreening" (successive credit extension to borrowers otherwise unable to service debt) is probably the single most important way to ease SME financing (Darvas, 2013). SMEs are also benefitting from targeted central bank lending through the Funding for Growth Scheme, which provides banks with zero per cent interest funding to lend to SMEs in forints or to convert outstanding SME foreign currency loans into forints at a maximum 2.5\% interest rate. Further, to give SMEs easier and cheaper access to finance, credit guarantee schemes were bolstered in 2013 with a 75 basis point budget subvention to reduce guarantee fees for a wide range of loan types. However, as discussed below, more should be done, on both debt and equity finance fronts. Since late and non-payments are a major problem in Hungary (Intrum Justitia, 2013), a further way to reduce firms' liquidity and financing strains is to cut payment delays in the public sector, building on recent progress in this area.

Greater reliance on bank financing, more informational asymmetries and less bargaining power make SMEs more vulnerable than large firms to competition problems in the banking sector, discussed in the financial stability chapter of the 2012 OECD Economic Survey of Hungary (OECD, 2012; Havrylchyk, 2012). One important dimension is transparency about credit eligibility and conditions, the lack of which 
often discourages SMEs from even applying for credit (Brown et al., 2011; Ministry for National Economy, 2012). In this vein, rules to curb unilateral contract modification by banks, now essentially confined to household mortgage loans concluded after April 2012, should be extended to all types of loans. As discussed above, fewer administrative burdens, as envisaged by the authorities, would foster less informality and hence more transparency on the SME side.

Deepening credit information would help both banks to credit-score their clients and clients to switch banks. For this purpose, credit information from non-bank sources (such as retailers or utilities) should be included in credit bureaus, which is not yet the case with BISZ, the main credit bureau in Hungary. Better information on individuals is also relevant for SME lending, as entrepreneurs, even when not personally liable for their business, are often required to provide personal guarantees when seeking a loan. BISZ used to collect both positive and negative information on firms, but only negative data on individuals. Legislation passed in October 2011 requiring BISZ to also provide positive information on individuals has had limited effect so far, since only about $20 \%$ of the borrowers with positive debt history have given the needed consent for such information to be disclosed and kept after the respective loan is terminated. Though consent is often also required abroad (Rothemund and Gerhardt, 2011), in the light of low financial literacy in Hungary the authorities should go further and impose mandatory disclosure and storage of positive information, without giving borrowers the right to opt out.

Equity finance is especially important for young innovative firms, which are often unable to borrow due to lack of collateral and track record. Venture capital investments have substantially increased in Hungary, which among EU countries leapt from one of lowest values as a share of GDP in 2009 to the highest $(0.065 \%)$ in 2012 . This largely reflects EU-funded public programmes, and most prominently the New Széchenyi Venture Capital Programme, endowed with over HUF 30 billion $(0.1 \%$ of GDP) in 2009-13, which makes investments in mostly high-technology young firms with private sector co-financing. In contrast, another EU-funded vehicle, the HUF 14 billion Széchenyi Fund for Capital investments (SZTA), relays venture capital to a wide variety of economic sectors, including low-technology activities like hospitality and furniture production. To maximise impacts on productivity and growth, public venture capital programmes should be better targeted to innovative firms and undergo systematic evaluation.

Reforms in bankruptcy laws are also needed to support innovative SMEs and entrepreneurship. Conversely to the ability to rapidly scale up production when innovation proves successful, swift exit in case of failure is essential to maximise salvage value and give entrepreneurs a second chance. Corporate insolvency procedures in Hungary are lengthy and, largely as a consequence, lead to an internationally low recovery rate $(38 \%$ against $68 \%$ across the OECD, according to World Bank and IFC, 2013). This penalises creditors (and thus harms credit availability) and hampers resource reallocation (Andrews and Criscuolo, 2013). The authorities should therefore take steps to shorten the duration of corporate insolvency procedures, for instance by introducing out-of-court settlements and simplified procedures for micro and small firms. As for private individuals, introducing a personal insolvency framework may reduce the time needed for debt discharge and therefore favour entrepreneurship and risk-taking.

\section{Barriers to entry are high in retail and professional services}

There is ample scope to spur competition and productivity growth in retail, where restrictive regulations, already significant in 2008, have recently tightened (Figure 9). The share of small shops, generally of low productivity (only 64\% of the sector average in 2010), is high (Figure 10, Panel A) and the fall in their numbers has noticeably slowed down since the mid-2000s. This may help explain an upward trend in the relative price of food (Figure 10, Panel B), in contrast with developments in the first half of the decade, when rapid expansion of modern retailers, often owned by international chains, moderated food inflation (Igan and Suzuki, 2012). 
Figure 9. Product market regulation in the retail sector ${ }^{1}$

Index scale of 0-6 from least to most restrictive

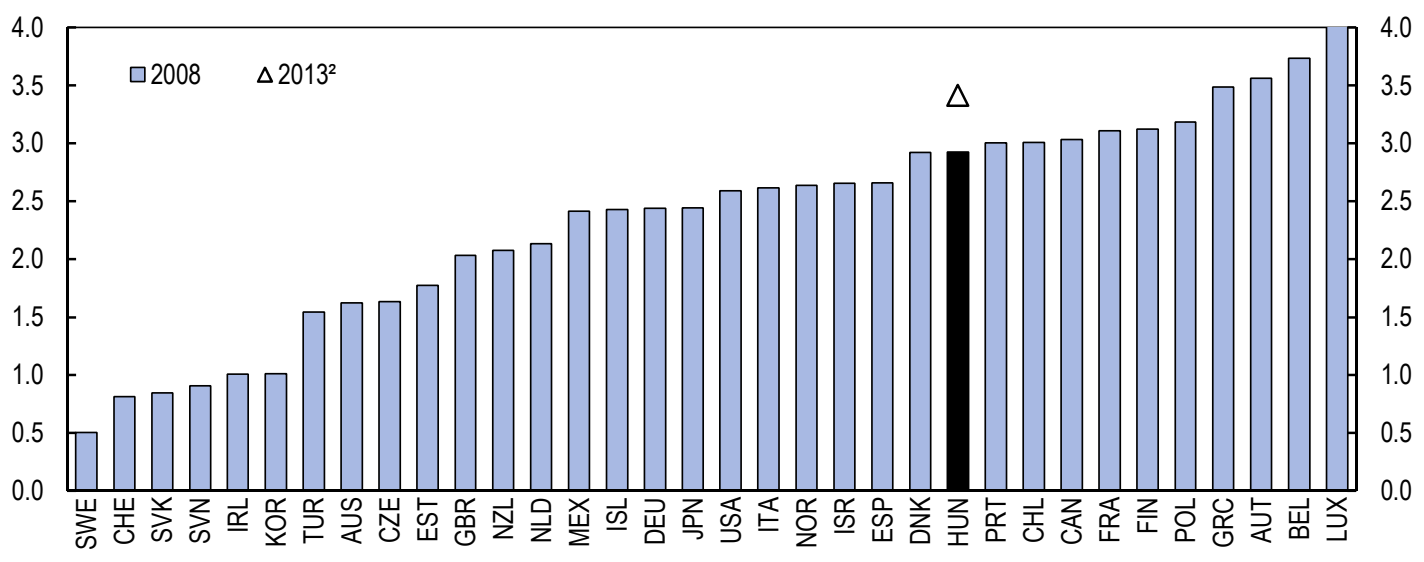

1. Barriers to entry in retail trade covering licences or permits needed to engage in commercial activity, specific regulation for large outlets and protection of existing firms.

2. Preliminary data calculated on the basis of the 2008 methodology for purposes of comparability. For more details, see Koske et al. (2014) which provides the 2013 indicators with a revised methodology.

Source: OECD (2013), OECD Product Market Regulation Statistics (database), July and I. Koske, I. Wanner, R. Bitetti and O. Barbiero (2014), "The 2013 Update of the OECD Product Market Regulation Indicators: Policy Insights for OECD and non-OECD Countries", OECD Economics Department Working Papers, forthcoming.

Figure 10. Indicators on retail firms and prices
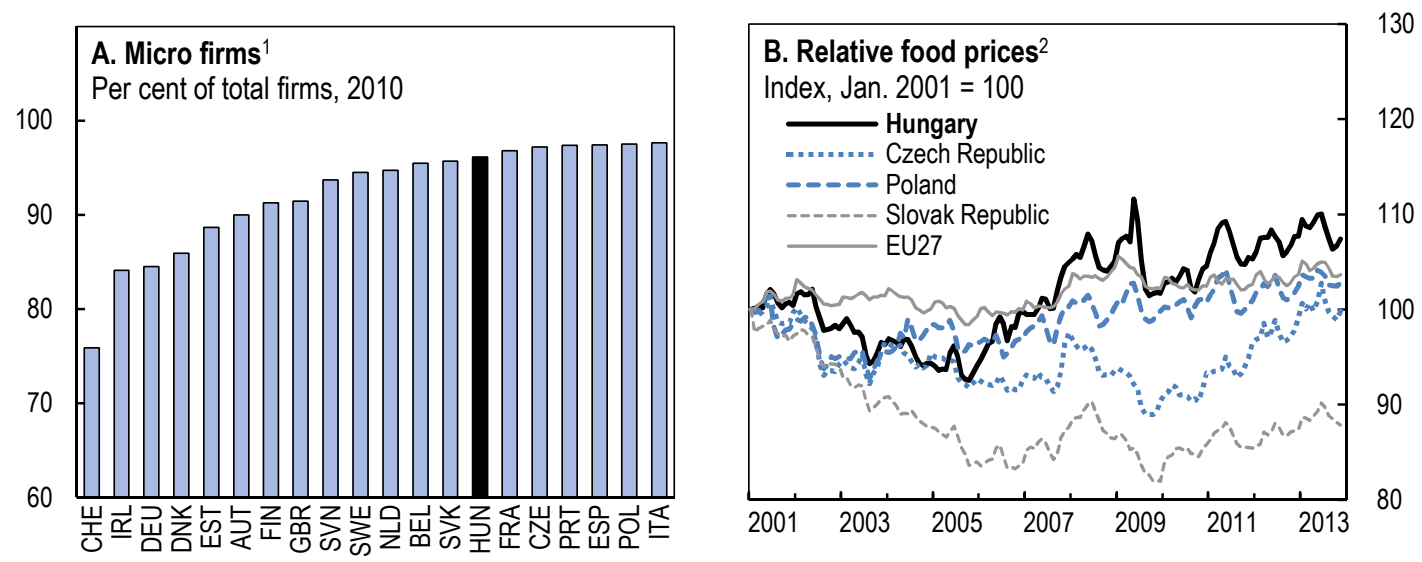

1. Firms with less than ten employees in the retail trade (excluding motor vehicles and motorcycles).

2. Prices of food and non-alcoholic beverages relative to all consumer prices (harmonised indices of consumer prices).

Source: OECD (2013), Structural and Demographic Business Statistics (database), December and Eurostat (2013) "Economy and Finance - Prices", Eurostat Database, December.

A major barrier to entry was added in 2012 by requiring government permission for new commercial buildings exceeding 300 square metres, a provision to stay in force until end-2014. The low threshold will bind virtually all modern-format retailers, such as hypermarkets, supermarkets and discounters (Igan and Suzuki, 2012). Further, the ministerial committee which assesses requests has denied permission in almost half of the cases so far. It has ample room for discretion, as legal provisions give no clear guidelines on the environmental and urban planning criteria to be taken into account. Retailers wishing to expand have often opted for purchasing existing stores rather than trying to build new ones, which helps explain a high number of mergers in the food retail market in 2012-13 (GVH, 2013). Higher market concentration ensues. The authorities should substantially raise the large outlet threshold and set out clear criteria for deciding on 
requests. Competition should be further enhanced by reducing retail-specific administrative burdens, such as those pertaining to other permits and licences.

Restrictive regulation for specific products has also been introduced. To make tobacco less accessible, especially for the youth, tobacco retail was monopolised from July 2013. Licensed retailers, selected through tenders and expected to reach around 5000 nationwide, are around nine times less numerous than tobacco vendors before, and also enjoy a higher profit margin (10\%). Post-monopolisation data shows a marked increase in tobacco prices (12\% in June-November 2013), while expected tobacco excise revenues in 2013 were slightly revised downwards, and are forecast to decline further in 2014, in contrast with strong increases in 2011-13 on the back of excise hikes.

Monopolisation may thus be leading to higher profits for the few licensed retailers to the detriment of the public purse. A related concern is black market growth, as the geographical distribution of retailers is uneven, with only gradual improvement in the coverage of small settlements. The authorities should consider further rising tobacco excises as an alternative to monopolisation. Part of the increased revenues could finance strict enforcement of the current ban on sales to minors across a wider network of points of sale.

Barriers to entry have also been raised in the pharmacy sector. After substantial liberalisation in 2006, which made the number of pharmacies increase by around 20\%, 2010 legislation reinstated geography and demography-based entry barriers (minimum thresholds for residents per pharmacy and distance between pharmacies) as well as ownership constraints. Pharmacists must own a majority stake by January 2017, a requirement which is currently not met by around one third of all pharmacies. Further, one pharmacist can own only four pharmacies (existing larger chains will not be disintegrated and will have a transition period to move to majority control by a pharmacist). Some evidence suggests that restrictions of this kind lower productivity and allocative efficiency without offsetting gains in service quality (ECORYS, 2007).

The worthy aim of protecting public health may be attained in less restrictive ways. For instance, professional oversight and counselling may be ensured by requiring a pharmacist's presence, rather than ownership. Restrictive practices stemming from wholesaler ownership - which were in any case not detected in 2006-10 - may be tackled under competition law. The authorities should therefore roll back the restrictions introduced in 2010. They should also expand the range of over-the-counter medicines that can be sold outside pharmacies.

Impediments to competition in professional services are internationally high (Figure 11), both as regards conduct regulations (see below) and barriers to entry. The latter mainly stem from lengthy training requirements, both in higher education and as compulsory practice, and extensive exclusive rights for service provision. Accounting and legal services, needed by the vast majority of firms, are among those most tightly regulated. If sustained, the recent sharp decrease in admissions to certain tertiary education programmes, including economics and law, partly induced by an even sharper fall in the number of statefinanced (i.e. tuition fee-exempt) positions available (see Sorbe, 2014), will in the medium term also restrict entry in the corresponding professional services. 
Figure 11. Barriers to competition in professional services ${ }^{1}$

Index scale of 0-6 from least to most restrictive

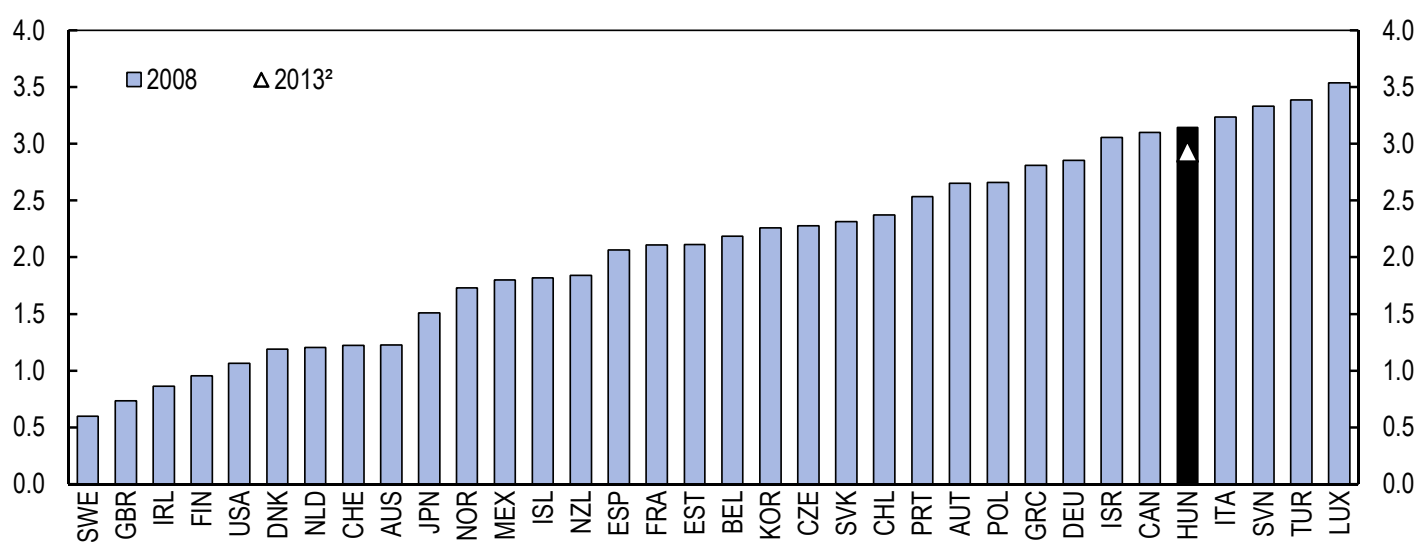

1. This indicator covers entry and conduct regulation in the legal, accounting, engineering, and architectural professions.

2. Preliminary data calculated on the basis of the 2008 methodology for purposes of comparability. For more details, see Koske et al. (2014) which provides the 2013 indicators with a revised methodology.

Source: OECD (2013), OECD Product Market Regulation Statistics (database), July and I. Koske, I. Wanner, R. Bitetti and O. Barbiero (2014), "The 2013 Update of the OECD Product Market Regulation Indicators: Policy Insights for OECD and non-OECD Countries", OECD Economics Department Working Papers, forthcoming.

Anti-competitive price and fee regulations are common. As an exemption from competition law, many professional chambers, including those for architects, engineers and auditors, are entitled to set recommended prices for certain services. Though not legally enforceable, in practice those prices often become the standard. Competition is also limited by the fact that, due to their high degree of informality, many SMEs find it hard to change lawyers or accountants (locking-in effects). The authorities should curb the right to make price recommendations. They should also review training requirements and exclusive rights and aim at reducing them, as international comparisons suggest that current restrictions go beyond what is needed for adequate consumer protection.

\section{Cuts in regulated energy prices harm competition, competitiveness and the environment}

Energy markets often remain highly concentrated. In wholesale, the electricity incumbent, stateowned MVM, has also recently purchased a leading position in gas import and storage. Gas consumption is covered mainly from imports delivered only via two pipelines and largely takes place under a single longterm contract. In electricity and gas retail, regulated-price and liberalised markets coexist, with access to the former restricted since 2008-09 to small consumers (mainly households). Concentration is also high, as the few firms servicing the regulated-price segments (universal service providers, USPs), generally part of vertically-integrated groups, also have prominent positions among free market suppliers (traders). District heating service provision is not competitive, as each provider (around 100 in total, mostly owned by municipalities) operates in its own supply area.

Further progress in cross-border interconnections and regional market integration will enhance competition in wholesale markets and security of supply. In electricity, market coupling with the Czech Republic and Slovak Republic since September 2012 has reduced Hungarian wholesale prices, although interconnection bottlenecks still hinder full price convergence. In gas, where wholesale prices are less transparent, the expiration in 2015 of the dominant wholesaler contract for imports from Russia and ongoing progress in international connections (most prominently a pipeline with the Slovak Republic, with completion due in 2015) offer increased possibilities of stronger wholesale competition. The authorities should continue to promote regional energy market integration. 
Other policy interventions have been less benign for market development. Since 2010, when a temporary price freeze was imposed, the authorities have increased their influence over regulated price setting, to the detriment of the sectoral regulator. In 2013, they cut regulated energy prices by a total of $20 \%$ (Box 3). Anti-competitive effects might result. As eligible consumers will tend to remain under (or return to) regulated prices, liberalised retail markets may not grow and smaller traders in these markets, likely less able to withstand a temporary profitability squeeze than vertically-integrated groups (REKK, 2010), may choose to exit. Further, the energy sector has been penalised with hefty taxes (Box 2), under which the effective corporate income tax rate can reach up to $50 \%$. Deteriorating profitability and regulatory uncertainty deter market entry and investment (IEA, 2011). Also due to a relatively high starting point, the energy sector stands out by its sharp fall in capital formation in the recent past (Figure 2), which, if sustained, would threaten secure energy supply in the long run, as acknowledged by the authorities (Ministry for National Development, 2012).

\section{Box 3. The implementation of the 2013 energy price cuts}

The 2013 20\% total cut in regulated energy prices (achieved in two equal steps, the first in January and the second in November) was implemented in different ways, reflecting the diverse price formation arrangements in electricity, natural gas and district heating.

In electricity, the regulated price paid by final consumers used to have four components: the price of electricity as a product (itself containing a universal service fee and the universal service providers [USPs] margin), the system usage charge, other financial tools (a component reflecting the cost of several support schemes, examples of which are given below) and value-added tax (VAT). The $20 \%$ cut was achieved through changes in the first three parts. The product price component was reduced, inter alia by some compression of the USPs margin. Further, USPs were released from the obligation to purchase their share of the more expensive electricity produced from renewables under feed-in tariffs, all of which must now be bought by free market traders and end-users importing electricity or buying it directly from generators. Cross-subsidisation was also present in the changes made to the second and third components of final prices. System usage charges were decreased for regulated-price consumers and increased for those in the free market, whereas other financial tools were fully shifted to the latter group of electricity users. According to preliminary estimates pertaining to the January price cut alone (REKK, 2013), ${ }^{*}$ the total transfer to regulated-price consumers in 2013 reached HUF 48 billion, with cross-subsidisation from the free market amounting to HUF 27 billion, the income of USPs and distributors decreasing by HUF 11 billion, and VAT revenues falling by HUF 10 billion. The full-year benefit to regulated-price consumers from the $20 \%$ total cut should therefore near HUF 100 billion (over $0.3 \%$ of GDP).

Before the price cuts, the regulated price of gas included a product fee, a base fee, a security storage fee and VAT. The base fee and the product fee cover the wholesale price, the margin of wholesalers, the costs of transport and storage, the distribution fee and the margin of USPs. The $20 \%$ reduction was achieved by eliminating the security storage fee and by decreasing both the base and the product fees. The total full-year transfer to regulated-price consumers is estimated by the authorities at around HUF 90 billion, with effects spread along the supply chain as well as lower VAT revenues. Around two-thirds of the pre-VAT burden are put on the domestic gas producer and on distributors.

In district heating there was a direct $20 \%$ total cut in the final end user prices charged by utilities. In 2011 heat producers, which supply those utilities, ceased to receive feed-in tariffs for electricity produced by cogeneration. To avoid that more expensive heat translated into higher prices for households, district heating utilities started to receive support from the compensation fund of district heating, itself financed from a new fee initially imposed on all electricity customers under the so-called other financial tools. Steps to finance the further losses of utilities due to the 2013 price cuts have included a reallocation within other financial tools and the introduction of cross-subsidisation from the gas market, as a similar fee was imposed on the domestic gas producer.

* REKK (2013), "Vihar a rezsiben: A REKK elemzése a 2013. januári rezsicsökkentésröl” (Storm in overhead costs: Analysis of the overhead reduction of January 2013 by REKK), Working Paper, No. 1, Regional Centre for Energy Policy Research, Corvinus University of Budapest.

Interventions in regulated prices have also worsened price distortions. In electricity, the implementation of the price cuts contains significant cross-subsidisation from industrial to residential users 
(Box 3). To the extent that gas firms pass burdens from regulated price cuts and subsidisation of district heating onto the free market, industrial users can also be affected. This hurts international competitiveness, especially as energy prices for industry are on the high side for gas and, for large users, electricity (Figure 12). Further, below-market prices for households, together with low excise taxation on energy use (see below), fail to provide incentives for energy efficiency. The authorities should move towards costreflective, market-based pricing in electricity and gas by vesting the right to set regulated prices in the sectoral regulator. In the longer term, strengthened competition in the liberalised market may allow gradually phasing out regulated prices. There will be a need to ensure that adequate safety nets are in place to shield the living standards of poorer households, which may require higher transfers to vulnerable consumers.

\section{Figure 12. Energy prices for industrial users}

Prices excluding value added tax, euro per kilowatt/hour, $2012^{1}$
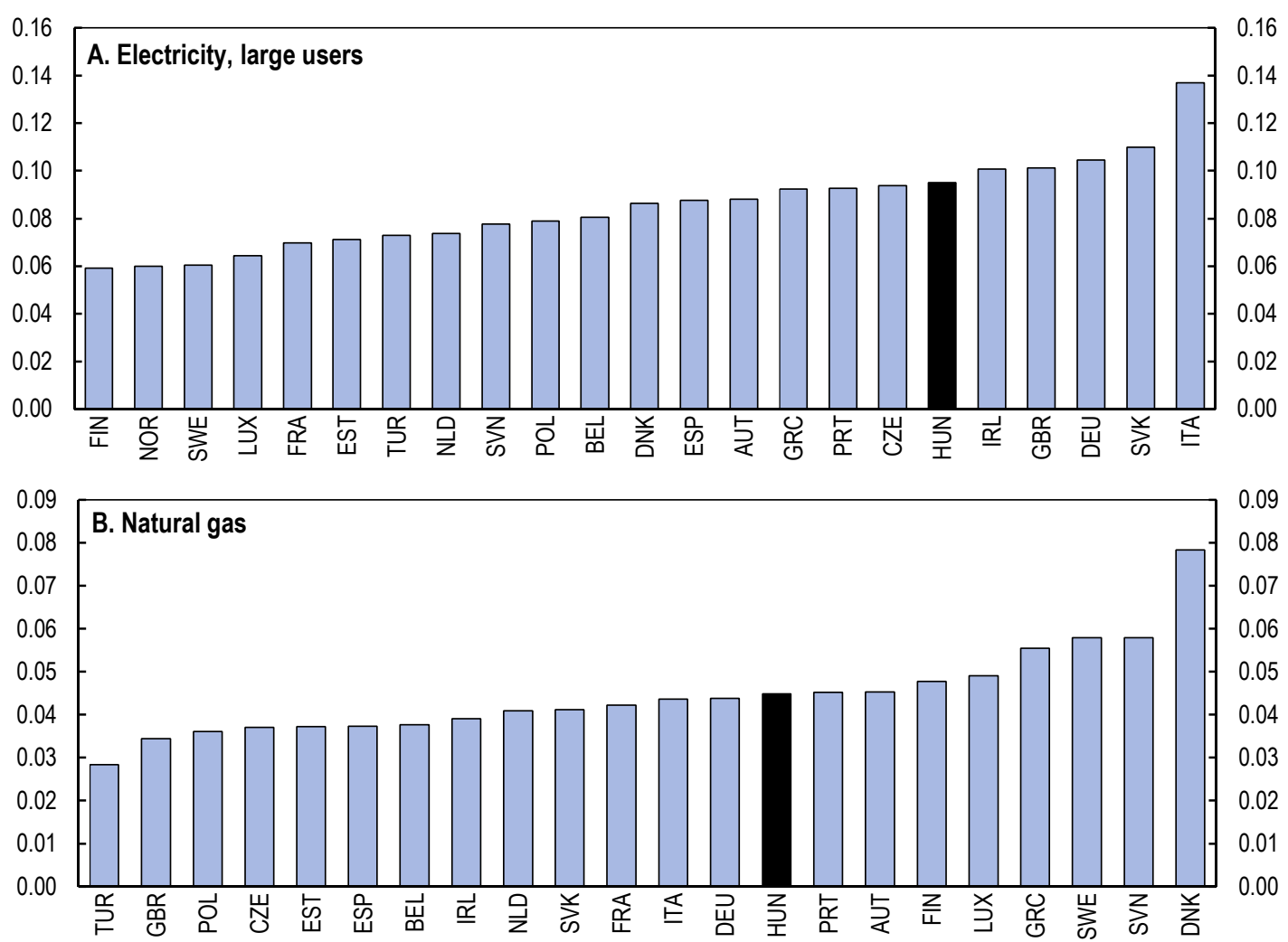

1. Average of data for the two semesters of 2012. Electricity covers the consumption band $20000-70$ 000 megawatt/hours and natural gas is an average of all consumption bands.

Source: Eurostat (2013), "Energy Statistics - Prices”, Eurostat Database, December.

There is significant scope to increase energy efficiency, especially as regards residential uses. Buildings account for $40 \%$ of all energy consumption (Ministry for National Development, 2012), a very high figure. Inefficiency problems are most acute in district heated homes, which house around $20 \%$ of the population. The authorities have long emphasised subsidies for energy efficiency projects, which remains a priority area in the National Energy Strategy (Ministry for National Development, 2012) and in the forthcoming EU funds programming period. Price incentives for energy efficiency are nonetheless blurred by the reduced 5\% VAT rate on district heating (since 2010) and very low energy excises (Figure 13). Energy use taxation should be increased, in tandem with stepped up efforts at individual metering and 
consumption control in district heated flats (where often they are still not possible) and the provision of consumer information about the benefits of energy-saving investments (such as insulation).

Figure 13. Low energy taxation for heating and electricity

Effective tax rate for all fuel use, euros per gigajoule ${ }^{1}$
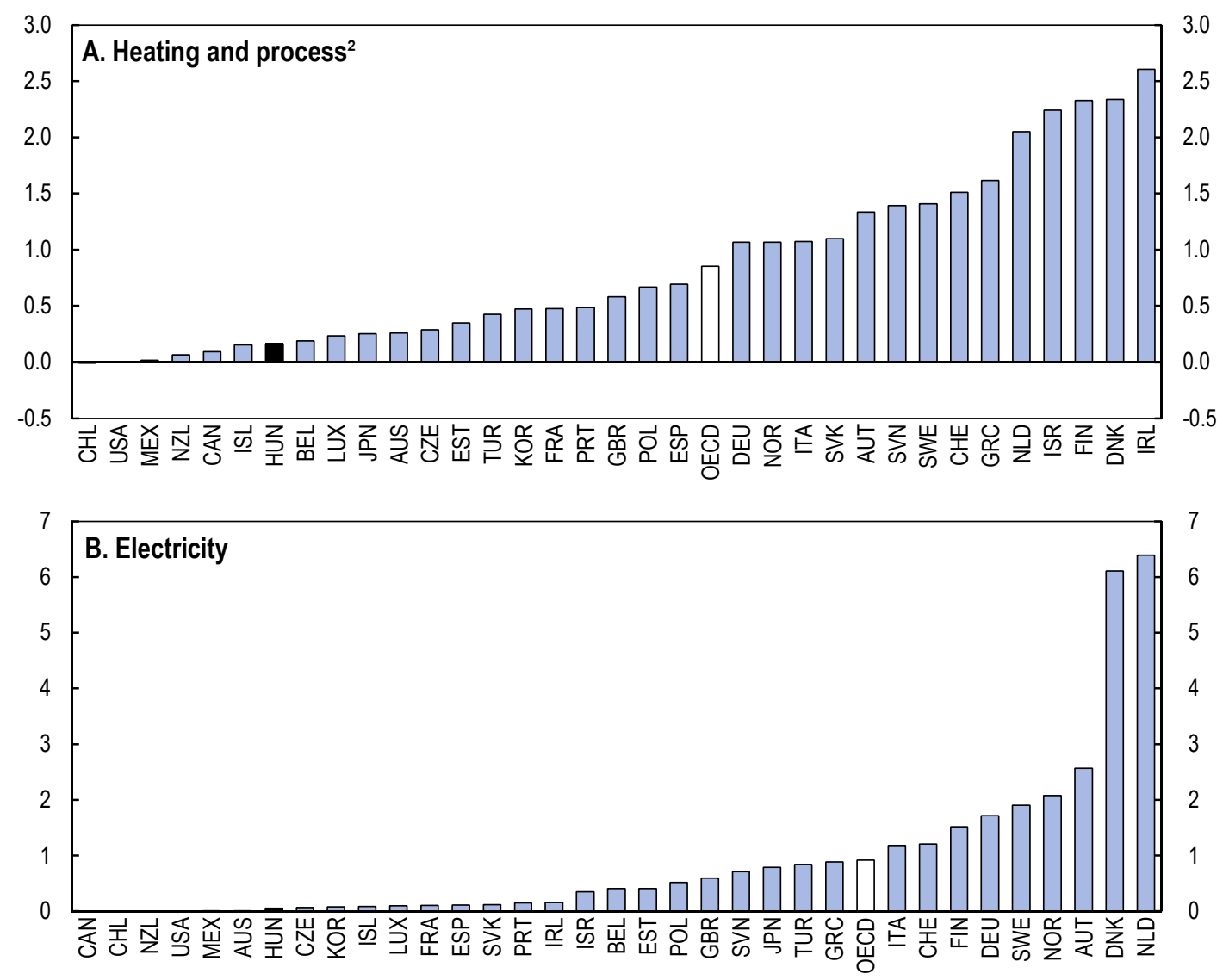

1. Tax rates are as of 1 April 2012 (1 July for Australia); energy use data is for 2009. Figures for Canada and United States only cover federal taxes. The OECD aggregate is an unweighted average.

2. Use of energy for space heating and in production processes. For Chile the negative amount reflects the credit provided by the Petroleum Price Stabilisation Fund for domestic kerosene.

Source: OECD (2013), Taxing Energy Use: A Graphical Analysis.

\section{There is scope to increase competition in mobile communications}

Expensive mobile telecommunications and low broadband penetration burden consumers and firms and hamper the economy's potential for innovation. Unlike fixed line calls and fixed broadband, mobile voice and smartphone-based data traffic is expensive in international comparison, especially in PPPadjusted terms (Figure 14) but often also at unadjusted exchange rates (OECD 2013e; Rewheel, 2013). High prices are particularly penalising given the large share of mobile networks in total voice traffic (78\% in 2011) and the growing delivery of bundled communications services on mobile phones. Fixed broadband penetration, at 22 subscriptions per 100 inhabitants, is somewhat below the OECD average (26 subscriptions, December 2012 data), though above regional peers. Wireless broadband penetration is very low (Figure 15), which high prices help to explain. This weakens the communications infrastructure with repercussions in many areas, such as innovation capabilities or the delivery of e-government services. 
Figure 14. Price of mobile communications

OECD mobile baskets including VAT, August 2012 (USD PPP) ${ }^{1}$
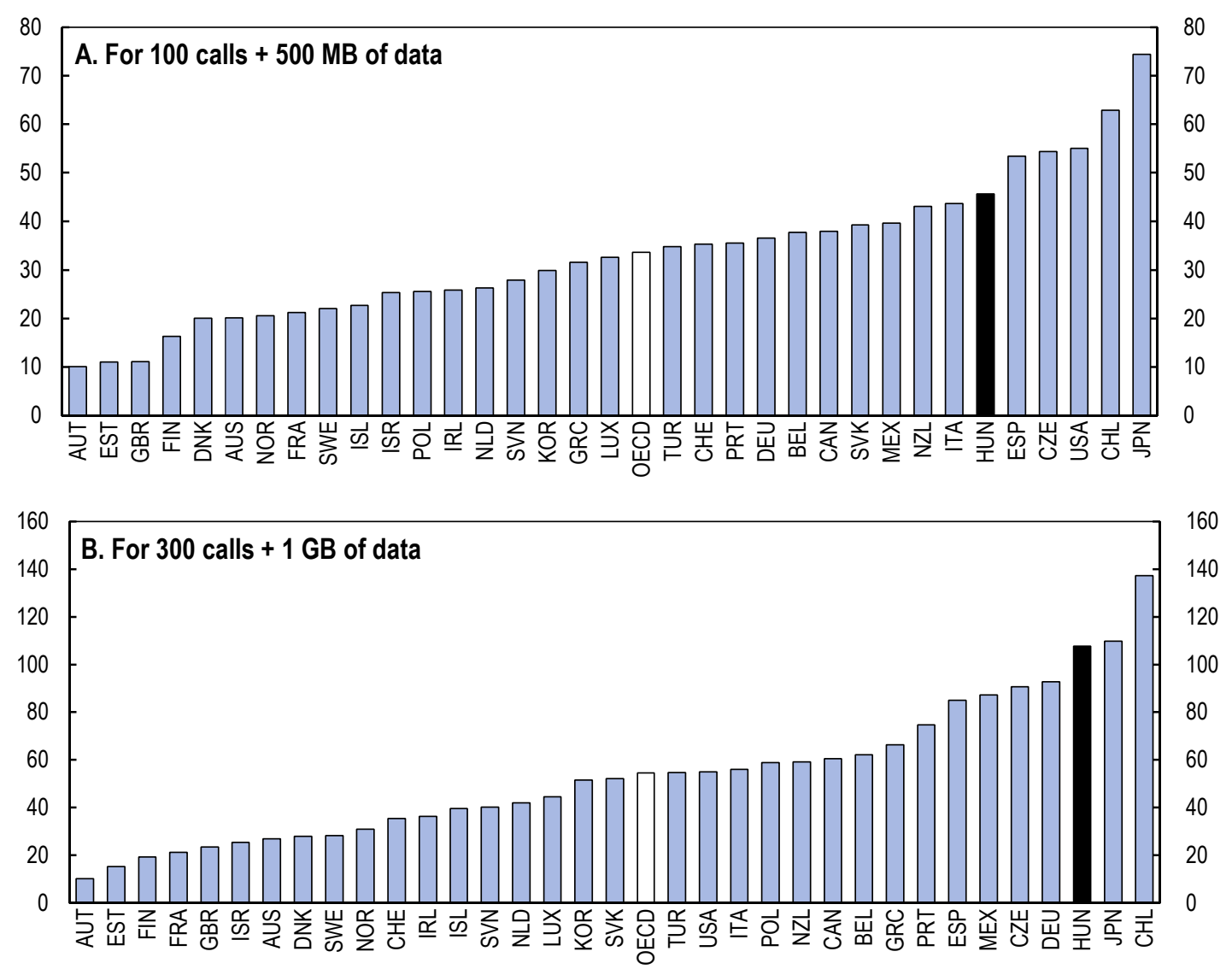

1. The OECD basket of mobile telephone charges includes fixed and usage charges per month (including value-added tax [VAT]) and is shown in US dollars at purchasing power parities (PPP). Charges are distributed between peak and off-peak hours and are based on an average call duration. The number of calls includes SMS messages: 140 SMS for 100 calls or 225 SMS for 300 calls.

Source: OECD (2013), OECD Communications Outlook 2013.

Figure 15. Wireless broadband penetration

Wireless broadband subscriptions per 100 inhabitants

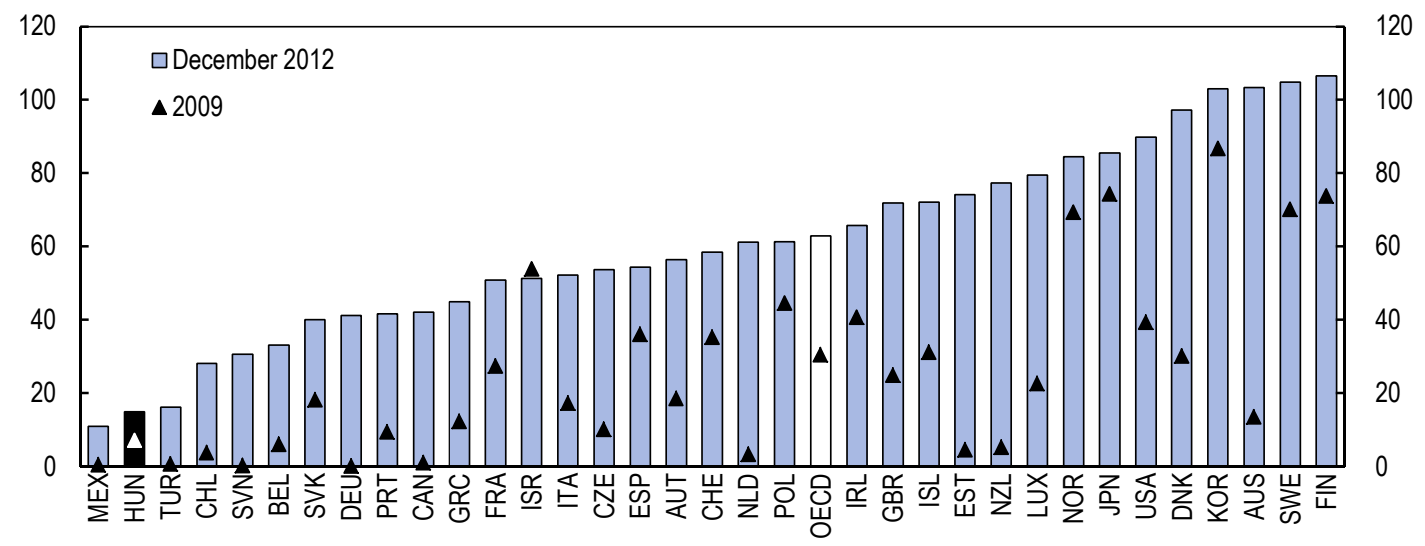

Source: OECD (2013), OECD Communications Outlook 2013 and OECD Broadband Statistics, www.oecd.org/sti/ict/broadband. 
The same three mobile network operators (MNOs, all belonging to multinational groups) have been in place since 1999, and the two largest operators had a joint share of $77 \%$ of subscribers in October 2012 (against $66 \%$ in the EU on average). The authorities have recently taken some pro-competitive steps, such as a decrease from eight to two in the working days needed to change operator while keeping the same number (from October 2012 onwards), but more needs to be done.

The potential of mobile virtual network operators (MVNOs) to enhance competition in mobile communications has so far failed to materialise. The two initial MVNOs providing voice services, each associated to a major retailer, started operations in 2012 and are estimated to have a joint share of around $1 \%$ of total subscriber identity module (SIM) cards, while in some countries with publicly available MVNO data the corresponding figure exceeds 10\% (European Commission, 2013b). Further, they are partial (and not full) MVNOs, as they have little or no technical autonomy from the respective host MNO, and mainly provide sales and marketing expertise targeted at low-end consumers. A third MVNO, also drawing on an existing network of shops (petrol stations, in this case) and operating along similar lines, was launched in 2013. The National Media and Infocommunications Authority (NMHH) has so far not intervened in the conditions of access to the host network (e.g. origination fees), and the current MVNOs were freely negotiated between the parties. However, it is doubtful that any of the MNOs would give access to a full MVNO under conditions enabling the latter to exert strong competitive pressure. The regulator should therefore ensure that potential entrants can buy full wholesale access to the existing physical networks on competition-enabling conditions.

Market entry by an additional MNO could also stimulate competition and bring about a significant drop in prices, as has recently been the case in countries like France or Israel (OECD, 2013e). Denmark, Israel, Slovenia and other countries show that more than three MNOs can be viable, even in small markets. An additional MNO may also ease MVNO entry, since a full MVNO can be a strong challenger to all operators with a physical network, but is at the same time a large customer of the host MNO. More competition among players with frequencies may therefore improve the bargaining position of prospective MVNOs. A spectrum auction held in 2011, which would have allowed the entry of a state-owned fourth mobile player, was later annulled by court decision, as two mutually contradictory decrees on frequency allocation were in force at the time. To enable entry, the regulator should therefore launch a new auction, building on consultations started in November 2013.

Recent special taxes are also likely to hamper competition and infrastructure development. Telecommunication investment fell by $27 \%$ in 2010 and by another $22 \%$ in 2011 (European Commission, 2013b), which could also be partly due to the aftermath of the 2009 recession. Besides running counter to government efforts to foster broadband expansion, such as the backhaul optical network development project, the new tax on wires and pipelines may well have anti-competitive effects: progressive rates (Box 2) are likely more than undone by the fact that incumbents are able to spread the tax liability from a given length of cables among their large client base, while smaller expanding firms are not. 


\section{Box 4. Main recommendations to enhance competition and the business environment}

\section{Reducing administrative burdens and regulatory instability}

- To improve regulatory quality and stability, introduce mandatory consultation with experts and stakeholders for parliament-initiated legislation, and further build capacity for high-quality regulatory impact assessment (RIA) of government-initiated legislation. Ensure timely and transparent related implementing regulations. RIA outputs and opinions delivered in consultations should be made public.

- To promote simplification and stability in taxation, curb tax expenditures and other special provisions, and consolidate several related taxes into fewer and broader ones.

- Promote greater coordination among government agencies. Fully implement the inter-operability of databases, while ensuring appropriate safeguards for data privacy and security.

- Foster systematic stakeholder involvement in the monitoring of administrative simplification programmes, the results of which should be made public.

\section{Strengthening institutional quality and competition enforcement}

- Do not restrict the scope of competition law and ensure vigorous antitrust enforcement.

- Systematically consult the Competition Authority, as well as relevant sectoral regulators, in draft legislation concerning their areas of competence.

Fostering growth of small and medium-sized enterprises and entrepreneurship

- $\quad$ Extend to all loans, both new and outstanding, rules to curb unilateral contract modification by banks.

- $\quad$ Further deepen information in credit bureaus, by including data from non-bank sources and imposing mandatory disclosure and storage of positive credit information on individuals.

- Increase the targeting of public venture capital programmes to innovative firms.

- To ease market exit in case of failure and foster entrepreneurship, shorten the duration of corporate insolvency procedures and introduce a personal insolvency framework.

\section{Promoting competition in retail and professional services}

- Decrease barriers to entry in retail through administrative simplification and by substantially raising the surface threshold for the regulation of large outlets (currently at 300 square meters).

- Reconsider training requirements and exclusive rights in professional services with a view to reducing them. Curb the right of professional chambers to make price recommendations.

- $\quad$ Liberalise the pharmacy sector by abolishing geography and demography-based entry barriers as well as ownership requirements by pharmacists.

\section{Promoting competition in energy and telecommunications}

- Move towards market-based pricing in electricity and gas by vesting the right to set regulated prices in the sectoral regulator.

- Continue to promote regional energy market integration through further progress in cross-border interconnections and market coupling.

- Increase energy use taxation, together with stepped up efforts at individual metering and consumption control in district heated flats and the provision of consumer information about the benefits of energysaving investments.

- In mobile telecommunications, ensure that mobile virtual network operators can buy full wholesale access to the existing physical networks on competition-enabling conditions.

- Launch a new spectrum auction to enable market entry by an additional mobile network operator. 


\section{Bibliography}

Alesina, A., S. Ardagna, G. Nicoletti and F. Schiantarelli (2005), "Regulation and Investment", Journal of the European Economic Association, Vol. 3, No. 4, MIT Press, http://dx.doi.org/10.1162/1542476054430834.

Andrews, D. and F. Cingano (2012), "Public Policy and Resource Allocation: Evidence from Firms in OECD Countries", OECD Economics Department Working Papers, No. 996, OECD Publishing, http://dx.doi.org/10.1787/5k9158wpf727-en.

Andrews, D. and C. Criscuolo (2013), "Knowledge-Based Capital, Innovation and Resource Allocation", OECD Economics Department Working Papers, No. 1046, OECD Publishing, http://dx.doi.org/10.1787/5k46bj546kzs-en.

Andrews, D., C. Criscuolo and C. Menon (2013), "Do Resources Flow to Innovative Firms? CrossCountry Evidence from Firm-Level Data" OECD Economics Department Working Papers, OECD Publishing, forthcoming.

Arnold, J., G. Nicoletti and S. Scarpetta (2011), "Regulation, Resource Reallocation and Productivity Growth", Nordic Economic Policy Review, No. 2, Nordic Council of Ministers.

Balás, G., B. Csita, Á. Szabó-Morvai and B. Szepesi (2010), “Bizalom és Vállalkozás Magyarországon: Kiindulópontok" (Trust and business in Hungary: Starting points), Bizalom és Vállalkozás Program Mühelytanulmányok II, Hétfa Research Institute.

Bottini, N. and M. Molnár (2010), "How Large are Competitive Pressures in Services Markets?: Estimation of Mark-ups for Selected OECD countries", OECD Journal: Economic Studies, Vol. 2010/1, http://dx.doi.org/10.1787/eco_studies-2010-5kmh5x5dbkf8.

Brown, M., S. Ongena, A. Popov and P. Yesin (2011), "Who Needs Credit and Who Gets Credit in Eastern Europe?", Economic Policy, Vol. 26, No. 65, Blackwell Publishing.

Darvas, Z. (2013), "Banking System Soundness is the Key to More SME Financing”, Bruegel Policy Contribution, No. 2013/10, July, Breugal.

Deloitte (2009), “Áttekintő vizsgálat az államigazgatási szabályozásból fakadó vállalkozói adminisztratív terhek teljes köréről, illetve egyes fókuszterületekkel kapcsolatosan részletes felmérések elkészítése" (Overview analysis of corporate burdens related to administrative regulation, and preparation of detailed surveys on some focus areas), Final Report.

ECORYS (2007), Study of Regulatory Restrictions in the Field of Pharmacies, Report for the Internal Market and Services DG, European Commission.

European Commission (2013a), 2013 SMEs' Access to Finance Survey: Analytical Report, DG Enterprise and Industry, November.

European Commission (2013b), "Electronic Communications Market Indicators", http://ec.europa.eu/digital-agenda/en/news/electronic-communications-market-indicators. 


\section{ECO/WKP(2014)19}

European Parliament (2013), "The Situation of Fundamental Rights: Standards and Practices in Hungary", Resolution of 3 July.

Gilardi, F. and M. Maggetti (2010), "The Independence of Regulatory Authorities", in D. Levi-Faur (ed.), Handbook on the Politics of Regulation, Edward Elgar Publishing.

Global Competition Review (2013), Rating Enforcement 2013, Law Business Research.

Government of Hungary (2013), National Reform Programme 2013 of Hungary.

GVH (2013), "Information about Mergers on the Food Retail Market", Press Release, 22 March, Hungarian Competition Authority.

Halpern, L. and B. Muraközy (2012), "Innovation, Productivity and Exports: The Case of Hungary", Economics of Innovation and New Technology, Vol. 21, No. 2, http://dx.doi.org/10.1080/10438599.2011.561995.

Havrylchyk, O. (2012), "Ensuring Stability and Efficiency of the Hungarian Financial Sector", OECD Economics Department Working Papers, No. 959, OECD Publishing, http://dx.doi.org/10.1787/5k98rwrzlgvj-en.

IEA (2011), Energy Policies of IEA Countries: Hungary 2011, International Energy Agency, OECD Publishing, http://dx.doi.org/10.1787/19900082.

Igan, D. and J. Suzuki (2012), "The 'Wal-Mart effect' in Central and Eastern Europe", Journal of Comparative Economics, Vol. 40, No. 2, Elsevier.

Intrum Justitia (2013), European Payment Index 2013.

Martonosi, A. (2013), "Factors Underlying Low Investment in Hungary”, MNB Bulletin, January, Magyar Nemzeti Bank.

Ministry for National Economy (2012), "Nemzeti Tőkepiac Fejlesztési Program” (National capital market development programme), internal working document.

Ministry for National Development (2012), National Energy Strategy 2030.

North, D.C. (1990). Institutions, Institutional Change and Economic Performance, Cambridge University Press.

OECD (2013a), OECD Economic Surveys: Ireland 2013, OECD Publishing, http://dx.doi.org/10.1787/19990324 .

OECD (2013b), Tax Administration 2013: Comparative Information on OECD and Other Advanced and Emerging Economies, OECD Publishing, http://dx.doi.org/10.1787/9789264200814-en.

OECD (2013c), How's Life? 2013 Measuring Well-being, OECD Publishing, http://dx.doi.org/10.1787/23089679.

OECD (2013d), Entrepreneurship at a Glance 2013, OECD Publishing, http://dx.doi.org/10.1787/22266941. 
OECD (2013e), OECD Communications Outlook 2013, OECD Publishing, http://dx.doi.org/10.1787/19991460.

OECD (forthcoming), Hungary: Towards a Strategic State Approach, OECD Public Governance Reviews, OECD Publishing

OECD (2012), OECD Economic Surveys: Hungary 2012, OECD Publishing, http://dx.doi.org/10.1787/19990529.

OECD (2009), Indicators of Regulatory Management Systems, Regulatory Policy Committee 2009 Report, OECD Publishing.

OECD and WTO (2013), OECD-WTO Trade in Value Added (TiVA), Country Notes, May 2013, http://www.oecd.org/industry/ind/measuringtradeinvalue-addedanoecd-wtojointinitiative.htm.

REKK (2010), Hungarian Energy Market Report, No. 4, Regional Centre for Energy Policy Research, Corvinus University of Budapest.

Rewheel (2013), EU27 Mobile Data Cost Competitiveness Report, May.

Rodrik, D., A. Subramanian and F. Trebbi (2004), "Institutions Rule: the Primacy of Institutions Over Geography and Integration in Economic Development", Journal of Economic Growth, Vol. 9, No. 2, Springer, http://dx.doi.org/10.1023/B:JOEG.0000031425.72248.85.

Rothemund, M. and M. Gerhardt (2011), "The European Credit Information Landscape: An Analysis of a Survey of Credit Bureaus in Europe", ECRI Research Report, No. 11, European Credit Research Institute.

Sorbe, S. (2014) "Tackling Labour Mismatches and Promoting Mobility in Hungary", OECD Economics Department Working Papers, forthcoming.

Thatcher, M. (2005), "The Third Force? Independent Regulatory Agencies and Elected Politicians in Europe”, Governance, Vol. 18, No. 3, Wiley, http://dx.doi.org/10.1111/j.1468-0491.2005.00280.x.

Tóth, P. (2013), "Hungarian Foreign Trade in the Light of TiVA Data: An Extended Country Note", Permanent Delegation of Hungary to the OECD, Hungarian version available at http://oecd.kormany.hu/szakmai-forum-a-globalis-erteklancok-szereperol.

Transparency International (2013), Global Corruption Barometer, www.transparency.org/gcb2013.

Venice Commission (2013), "Opinion on the Fourth Amendment to the Fundamental Law of Hungary, Adopted by the Venice Commission at its 95th Plenary Session", European Commission for Democracy through Law, 14-15 June, Venice.

World Bank and IFC (2013), Doing Business 2014: Understanding Regulations for Small and MediumSize Enterprises, World Bank and International Finance Corporation.

World Bank, IFC and PwC (2013), Paying Taxes 2014: The Global Picture, World Bank, International Finance Corporation and PricewaterhouseCoopers.

World Economic Forum (2013), The Global Competitiveness Report 2013-2014.

World Economic Forum (2012), The Global Competitiveness Report 2012-2013. 
ECO/WKP(2014)19

\section{WORKING PAPERS}

The full series of Economics Department Working Papers can be consulted at www.oecd.org/eco/workingpapers

1122. Tackling labour mismatches and promoting mobility in Hungary

(June 2014) by Stéphane Sorbe

1121. Local public finances and municipal reform in Finland

(June 2014) by Christophe André and Clara Garcia

1120. The economic consequences of ageing: the case of Finland

(June 2014) by Christine de la Maisonneuve, Christophe André, Clara Garcia and Vincent Koen

1119. Making the most of skills in Denmark

(June 2014) by Stéphanie Jamet and Vincent Koen

1118. Trade specialisation and policies to foster competition and innovation in Denmark

(June 2014) by Müge Adalet McGowan

1117. Policies for making the Chilean labour market more inclusive

(June 2014) by Aida Caldera Sanchez

1116. Spillover effects from exiting highly expansionary monetary policies

(May 2014) by Łukasz Rawdanowicz, Romain Bouis, Jérôme Brezillon, Ane Kathrine Christensen and Kei-Ichiro Inaba

1115. Economic policies and microeconomic stability: a literature review and some empirics (April 2014) by Paula Garda and Volker Ziemann

1114. How to improve Israel's health-care system

(April 2014) by Philip Hemmings

1113. How to improve taxes and transfers in Israel

(April 2014) by Philip Hemmings

1112. New evidence on the determinants of industrial specialisation

(April 2014) by Asa Johansson and Eduardo Olaberria

1111. Economic growth from the household perspective: GDP and income distribution developments across OECD countries

(April 2014) by Orsetta Causa, Sonia Araujo, Agnès Cavaciuti, Nicolas Ruiz and Zuzana Smidova

1110. Would a growth slowdown in emerging markets spill over to high-income countries? A quantitative assessment

(April 2014) By Patrice Ollivaud, Elena Rusticelli and Cyrille Schwellnus

1109. Short-term indicator models for quarterly GDP growth in the BRIICS: A small-scale bridge

model approach

(April 2014) by Thomas Chalaux and Cyrille Schwellnus 
1108. The prudential regulation of financial institutions: why regulatory responses to the crisis might not prove sufficient

(March 2014) by William R. White

1107. OECD forecasts during and after the financial crisis: a post mortem

(March 2014) by Nigel Pain, Christine Lewis, Thai-Thanh Dang, Yosuke Jin and

Pete Richardson

1106. Fairly sharing the social impact of the crisis in Greece

(January 2014) by Vassiliki Koutsogeorgopoulou, Manos Matsaganis, Chrysa Leventi and Jan-David Schneider

1105. Dividing the pie in Brazil: income distribution, social policies and the new middle class

(January 2014) by Jens M. Arnold and João Jalles

1104. New indicators of competition law and policy in 2013 for OECD and non-OECD countries (December 2013) by Enrico Alemani, Caroline Klein, Isabell Koske, Cristiana Vitale and Isabelle Wanner

1103. The effect of government debt, external debt and their interaction on OECD interest rates (December 2013) by David Turner and Francesca Spinelli

1102. The state of the banking sector in Europe

(December 2013) by Dirk Schoenmaker and Toon Peek

1101. Getting Irish youth on the job track

(December 2013) by Alberto González Pandiella

1100. New econometric estimates of long-term growth effects of different areas of public spending (December 2013) by Omar Barbiero and Boris Cournède

1099. Cross-country spillovers from fiscal consolidations

(December 2013) by Antoine Goujard

1098. Informal employment in Russia: definitions, incidence, determinants and labour market segmentation

(December 2013) by Hartmut Lehmann and Anzelika Zaiceva

1097. Capacity needs in the automobile industry in the short- to medium run

(November 2013) by Caroline Klein and Isabell Koske

1096. Environmental policies and productivity growth - a critical review of empirical findings

(November 2013) by Tomasz Koźluk and Vera Zipperer

1095. Green growth challenges and the need for an energy reform in Mexico

(November 2013) by Carla Valdivia de Richter

1094. From bricks to brains: increasing the contribution of knowledge-based capital to growth in Ireland

(November 2013) by David Haugh 